\title{
Comparative study of Wenner and Schlumberger electrical resistivity method for groundwater investigation: a case study from Dhule district (M.S.), India
}

\author{
Baride Mukund Vasantrao $^{1} \cdot$ Patil Jitendra Bhaskarrao $^{1} \cdot$ Baride Aarti Mukund $^{1}$. \\ Golekar Rushikesh Baburao ${ }^{2} \cdot$ Patil Sanjaykumar Narayan $^{3}$
}

Received: 6 December 2016/Accepted: 18 May 2017/Published online: 1 June 2017

(c) The Author(s) 2017. This article is an open access publication

\begin{abstract}
The area chosen for the present study is Dhule district, which belongs to the drought prone area of Maharashtra State, India. Dhule district suffers from water problem, and therefore, there is no extra water available to supply for the agricultural and industrial growth. To understand the lithological characters in terms of its hydrogeological conditions, it is necessary to understand the geology of the area. It is now established fact that the geophysical method gives a better information of subsurface geology. Geophysical electrical surveys with four electrodes configuration, i.e., Wenner and Schlumberger method, were carried out at the same selected sites to observe the similarity and compared both the applications in terms of its use and handling in the field. A total 54 VES soundings were carried out spread over the Dhule district and representing different lithological units. The VES curves are drawn using inverse slope method for Wenner configuration, IPI2 win Software, and curve matching techniques were used for Schlumberger configuration. Regionwise lithologs are prepared based on the obtained
\end{abstract}

Electronic supplementary material The online version of this article (doi:10.1007/s13201-017-0576-7) contains supplementary material, which is available to authorized users.

Golekar Rushikesh Baburao

rbgolekar@gmail.com

1 Department of Geology, Z. B. Patil College, Dhule, M.S. 424002, India

2 Department of Geology, G.B. Tatha Tatyasaheb Khare Commerce, Parvatibai Gurupad Dhere Art's and Shri. Mahesh Janardan Bhosale Science College, Dist. Ratnagiri, Guhagar, M.S. 415703, India

3 Department of Applied Geology, School of Environmental and Earth Sciences, North Maharashtra University, Jalgaon, M.S. 425001, India resistivity and thickness for Wenner method. Regionwise curves were prepared based on resistivity layers for Schlumberger method. Comparing the two methods, it is observed that Wenner and Schlumberger methods have merits or demerits. Considering merits and demerits from the field point of view, it is suggested that Wenner inverse slope method is more handy for calculation and interpretation, but requires lateral length which is a constrain. Similarly, Schlumberger method is easy in application but unwieldy for their interpretation. The work amply proves the applicability of geophysical techniques in the water resource evaluation procedure. This technique is found to be suitable for the areas with similar geological setup elsewhere.

Keywords Geophysics · Groundwater - Exploration · Vertical electrical sounding - Wenner and Schlumberger

\section{Introduction}

Long years ago, humanity existed in groups and rarely in larger numbers. Therefore, there was a type of absorbance within the community if any natural or anthropogenic changes took place. However, over a period of time, the human race has seen explosion in technology and population obviously for both categories: the rich out of greed and poor out of need. This has definitely placed pressure on whatever natural resources we have, which includes environment and space. The world population has increased sharply in a very short period of time and death has been prolonged due to the lowering of death rate. Urbanization rules the divide between rural and urban populations. The impact of urbanization and industrial development is being seen as a negative stress put on atmosphere, hydrosphere, 
lithosphere, and on human beings in general, life in particular. The rate at which the development is taking place is going to lead to no where and has bearing on water resources. One such impact is now being seen on water resource more than other natural resources as water is now being considered as an important natural resource.

Many researchers have studied the area from different point of views. The Geological Survey of India published report on the Geology of Dhule district (Geological Survey of India 1976). Some aspects of hydrogeology of Maharashtra have been attempted by earlier researchers (Adhyalkar and Mani 1972; Adhyalkar 1975; Aurangabadkar 1990; Aurangabadkar and Waldhe 2001). The Deccan Volcanic activity and their characteristics are studied by Krishnan (1982). Startigraphic study has been carried out by few researchers (Powar 1987; Sethna et al. 1996; Vaidyanadhan and Ramakrishnan 2008).

Geophysics plays an important role in groundwater exploration. It is necessary to locate groundwater potential zones using cost-effective methods. As urban, agricultural, and industrial development, the volume and proportion of water required will also increase and water supplies that were obtained from shallow unconfined aquifers may not be sufficient, because the availability of the resources becomes confined. The water resources required will have to be tapped from deeper aquifers or, more often, can be drawn from aquifers or surface water bodies and reservoirs. Thus, importing of water becomes necessary for urban, agricultural, and industrial development. If this does not happen, then the development may get hampered. It is observed that very little work has been done in the area of studies with respect to correlation between Vertical Electrical Sounding studies (Erram et al. 2010).

The authors have made an attempt to correlate the VES methods of Wenner and Schlumberger in understanding the scientific principles. This will help the academicians to understand to practical importance of these methods.

\section{Study area}

The area chosen for the present study is Dhule district, which belongs to the drought prone area of Maharashtra state, India. Dhule district covers an area of $8063 \mathrm{~km}^{2}$. This is about $2.6 \%$ of the total land of the state (Fig. 1). According to 2011 census, the population of Dhule district is about 2050862. The population density of the Dhule district is about 254 per $\mathrm{km}^{2}$. The density needs to be critically reviewed as compared to the state's density. This indicates that increase in density will put pressure on the limits of urban cities and they will increase in size. This will give cumulative stress especially on water.

Physiographically, Dhule district is covered in Upper Tapi basin which forms the northern part of Maharashtra state. It is bounded by $20^{\circ} 38^{\prime \prime}-21^{\circ} 60^{\prime \prime}$ North latitude and $73^{\circ} 50^{\prime \prime}-75^{\circ} 11^{\prime \prime}$ East longitudes. Dhule district is bounded by Jalgaon district in the east, Nasik district forms the southern end, on the northern part is the Nemad district in Madhya Pradesh, and western side forms the Nandurbar district boundary. Dhule district is drained by rivers, such as Tapi, Panzra, Burai, Arunavati, Aner, Bori, Kan, and Amravati. These rivers are the major source for surface and groundwater in the district. The district is divided into three regions based on the type of soils which is low, medium, and black cotton soil. Low fertile land is about $60 \%$, medium fertile land is $25 \%$, and black cotton soil covers $15 \%$ of the area (Central Ground Water Board 2009).

The soils of the district are derived from weathering of basalt and from the river system. The alluvium is present along the rivers and along hill slope streams. These are light soils, dark brown to yellowish brown, and loamy-toclay loamy texture with sub-angular grains. The presence of clayey soil is towards south of Tapi valley (CGWB).

The climatic condition of Dhule district is hot and dry, arid to semi-arid type. Temperature is maximum $45^{\circ} \mathrm{C}$ and minimum of $06{ }^{\circ} \mathrm{C}$ in the months of May and October, respectively, with relative humidity $75 \%$ (Aurangabadkar 1990). In the district, June, July, August, and September are the rainfall months. The rainfall statistics for Dhule district shows that average rainfall is $771.0 \mathrm{~mm}$.

\section{Scope of the work}

There is need to understand the two important concepts with respect to water as: (1) sustainability and (2) management. To achieve sustainability, there is a need for rethinking of our basic needs. If our basic need is considered to be water on priority, then water as a resource must be valued as to how much of water do we really require and how much do we use. The need of water for ecosystem and the animal life too require water, and therefore, the basic needs to preserve and use water judiciously as a resource becomes our greatest challenge and to adopt sustainable practices. For managing this resource, information regarding the availability of subsurface water is important. With right information, effective communication using modern scientific knowledge and dialogue between individuals and institutes, water as a source can be understood and managed in a sustainable manner and, therefore, needs to focus on productive water by managing water in rain fed zones and sustainable use of groundwater through exploration method.

\section{Aims and objectives}

In the present study, geophysical approach has been adopted to investigate the subsurface lithology of the Dhule 
Fig. 1 Geological map of Dhule district (Source: GSDA 2001)

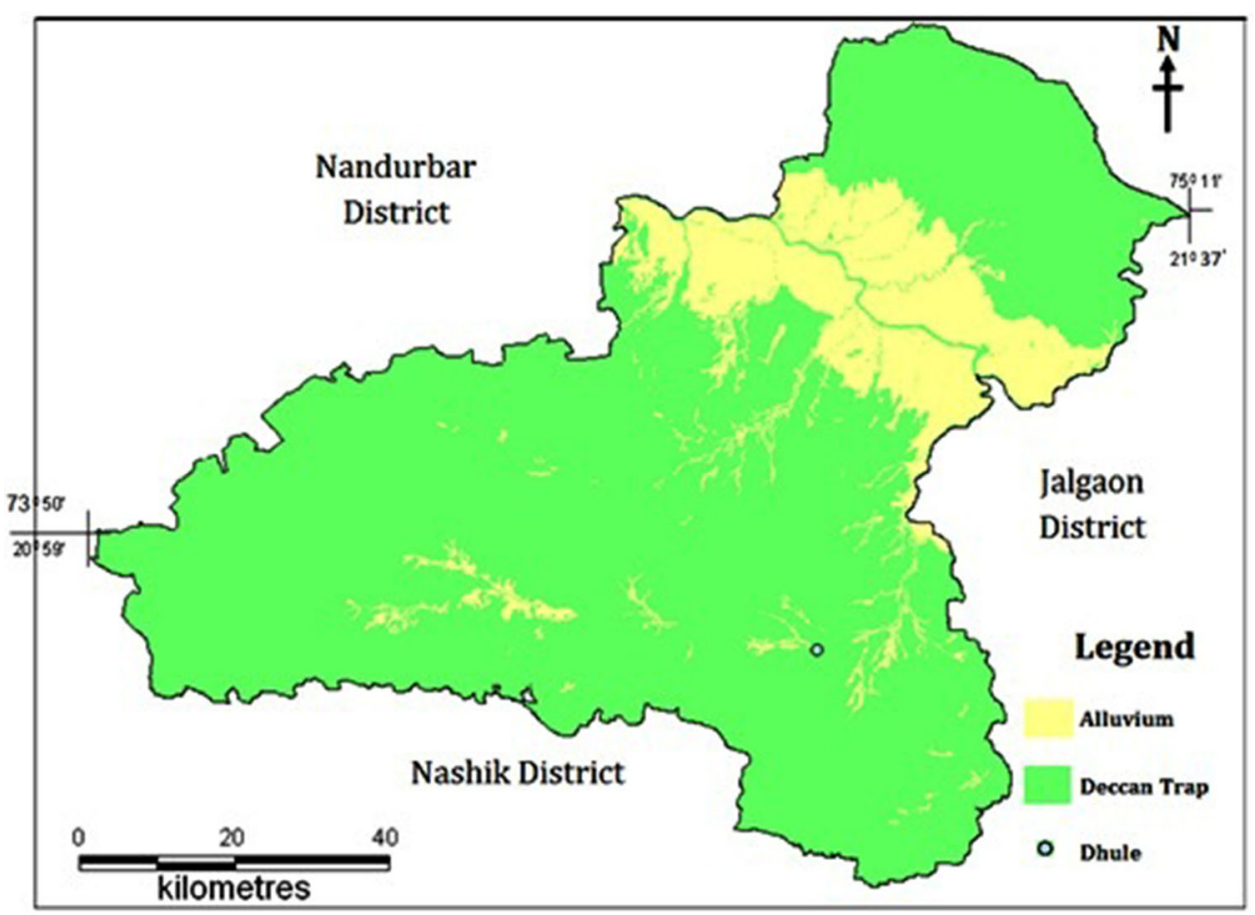

District located in Maharashtra state (India), with an aim to differentiate the aquifers and delineate the depth of aquifers and comparison between Wenner's and Schlumberger method.

\section{Geological setting}

Geology, topography, relief, climate, soils, temperature, rainfall, and other natural factors govern the development of groundwater. It is necessary to understand the basics of the terrain and river dynamics besides other factors in relation to groundwater occurrence and movement in the area.

\section{Regional geology}

Nearly, 65 million years ago, large amount of outpouring of molten lava took place through fractured Western India. The eruption is intermittent giving rise to Large Volcanic Province called Deccan Volcanic Province (Krishnan 1982; West 1988). It is most extensive lava eruption and formation in the Peninsular India. It is recognized as Deccan Trap and also called as Large Igneous Province (LIP). The term Deccan Trap is suggested by Sykes, meaning 'south' (Sykes 1833). The topography is typical step like.

The extent of DVP spreads over an area of about $5,00,000 \mathrm{~km}^{2}$ extending over large parts of Madhya Pradesh, Maharashtra, Gujarat, and some parts of Andhra Pradesh and Karnataka and also large part of the DVP is concealed under the Arabian Sea (Powar 1987). They are exposed along Sahyadri Mountains or Western Ghats with steep escarpments in west coast of India. The Ghat is a result of faulting to produce an Atlantic type of continental margin (Erram et al. 2010). The composite thickness may be about $3000 \mathrm{~m}$. Deccan Traps exhibit horizontal lava flows, development of flat-topped hills, and step-like terraces. The horizontal basaltic lava flows are inferred to be due to fissure eruptions (Vaidyanadhan and Ramakrishnan 2008; Bondre et al. 2006).

Earlier pioneer workers who studied DVP are stated that the basalts from the Deccan Province are vesicular with or without secondary zeolite material. The rock also shows a variety of joints and fractures. These fracture zones have become the path for drainage development and undulating topography (Blanford 1869; West 1972). The Deccan lavas are traversed by the number of dykes along Narmada-Tapi tectonic zones with ENE-WSW trend. Concentration of dyke is more in Nandurbar district and Konkan region. Some of the dykes form linear ridges for a long distance. Some dykes are eroded faster forming linear depressions. Geological map of Dhule district has depicted in Fig. 1.

\section{Lineaments and dyke intrusive from the study area}

The large number of dolerite dykes intrudes the basaltic lava flows in the study area. Dykes can act as pathways or as barriers to the groundwater flow depending upon the intensity of fracturing in the dyke rock (Babiker and Gudmundsson 2004; Gurugnanam et al. 2008). Whether 
the dykes act as water conduits or as barriers their structure, location and orientation with respect to the groundwater flow are important parameters (Gurugnanam et al. 2008; Singh and Jamal 2002). Dhule district of Maharashtra is known for the occurrence of dykes and dyke swarms (Geological Survey of India 2001). However, attempt to study the area from hydro-geological point of view has been done by few researchers (Duraiswami 2005; Pawar 2006; Gupta et al. 2012; GSDA 2001).

The trend of the majority of the lineaments is in the E$\mathrm{W}$ direction, and some of the lineaments show $\mathrm{N}-\mathrm{S}$, NNW-SSE, and NNE-SSW trend. The lineaments are the major fractures and dykes. The fractures are related to shears and the dykes appear to occupy dilatory tensional fractures. Dykes are vertical intrusions showing linear ridges due to differential weathering. They are simple and undifferentiated. The dykes trending E-W and ENE-WSW directions are parallel to the Narmada-Tapi-Satpura zones. These dykes extend for kilometers with varying thickness. The dykes belonging to these sets are generally coarse grained, gabbroic. The jointing pattern produces larger blocks. Dykes belonging to the north-south swarm are few in number and are exposed in the southern and western parts of the Panzra river (Sheth and Chandrasekharam 1997). Some of the dykes exhibit a negative relief at higher elevations but stand out as low elevation in the low lying areas. These are compact fine grained and exhibit closely spaced joints. Some of the dykes are partly concealed, while some are exposed in stream cuttings, dug well section, and road cuts. Dykes from the study area are in part responsible for controlling the topography of the basin. Systematic studies by adopting hydro-geological and geophysical (electrical resistivity and magnetic) approaches have not yet been attempted to indicate the status, occurrence, and movement of groundwater except by a few as already referred above.

Figure 2 shows that the presence of dykes, lineaments, and the drainage in Dhule district. It is observed that dykes trending east-west show branching and sharp cross-cutting relationship. Dykes show sharp contrast with the country rocks. Dykes trending E-W are generally dense, dark, less fractured, and moderately compact, whereas north-south trending dykes are moderately weathered and fractured. In the district EW trending, dykes run more or less parallel to the drainage and sometimes follow surface divides and act as barriers of ground water, while north-south trending dykes cut across the drainage and behave like conduits of groundwater (Sheth and Chandrasekharam 1997). The Flood Basalt is fissure-type volcanic activity, and therefore, dykes in large number are exposed in the Nandurbar and Dhule. In Dhule area, basalts show a thick sequence of about $870 \mathrm{~m}$ in Toranmal. It is dominated by columnar jointing simple flows, which are similar to that of Western
Ghat (Sheth and Pande 2004; Ray et al. 2007; Sant and Karanth 1990). Tertiary and quaternary alluvium is exposed along the major rivers. The lava flows are horizontal around Dhule and Dondaicha and Dips towards north at $5^{\circ}-10^{\circ}$ near Shahada and Kondaibari.

The dyke controlling local groundwater table in Sakri taluka has been reported by earlier researcher (Pawar 2006). The Narmada-Satpuda-Tapi dyke swarm is a liner ENE-WSW trending Giant dykes (Melluso et al. 1999). The petrographic and geochemical studies of dykes in Nandurbar Dhule area have been carried out by earlier researchers (Sheth 2005; Bhattacharji et al. 2004; Das Balaram Maity and Tarafdar 2007). Since the dykes are not emplaced along faults or fracture, it suggests regional horizontal compressive stress along north-south as a region for the emplacement of dyke (Sant and Karanth 1990).

\section{Alluvium}

Patches of alluvium are exposed along the Panzra river and its tributaries near villages Samode and Kasare, Dhadne, Morane, and Kundane-War. Small patches of alluvium are also found between Dahivel, Surpan, and Ashtane along the Kan river (GSDA 2001). The thick sequence of alluvium is found in the low lying areas between Sukwad and Vadali and at Bhadne. Primary sedimentary structures, such as parallel bedding, trough cross bedding, tabular cross bedding, and cut-and-fill structures, are seen in the litho-sections. Alluvial deposits of Tapi river valley occurs in long narrow basin, which are probably caused by faulting. About $15 \%$ of the district is occupied by alluvium consisting of clays, silt, and sand. The beds of sand and gravels are discontinuous and lenticular and pinch out laterally within short distance. They are mixed with large proportions of clayey material. Sections show the presence of more or less nodular calcrete material associated with alluvium. The deposit consisting of talus and scree locally known as Bazada zone forms colluvial deposits which have developed along foothills that overlie alluvium along stream banks. This zone consisting of poorly sorted unconsolidated large boulders, pebbles, and cobbles with sand is porous and has a capacity to accept higher quantity of water as recharge. The maximum thickness of this formation ranges from 35 to $40 \mathrm{~m}$.

Black cotton soil is the ultimate product of decomposition and weathering of basalt. The lava flows are covered by black clayey to loamy soil. The thickness of the soil is less than meter. However, in some part of Tapi river and Burai river, the thickness of soil ranges from 2 to $3 \mathrm{~m}$ admixed with local alluvium. The soil in the alluvial part along the Burai river is gray in color and at places unsuitable for irrigation due to their high sodium content. Light types of soil are good for cultivation in kharif crops 
Fig. 2 Map showing rivers, dykes, and lineaments in Dhule district [Source, GSDA]

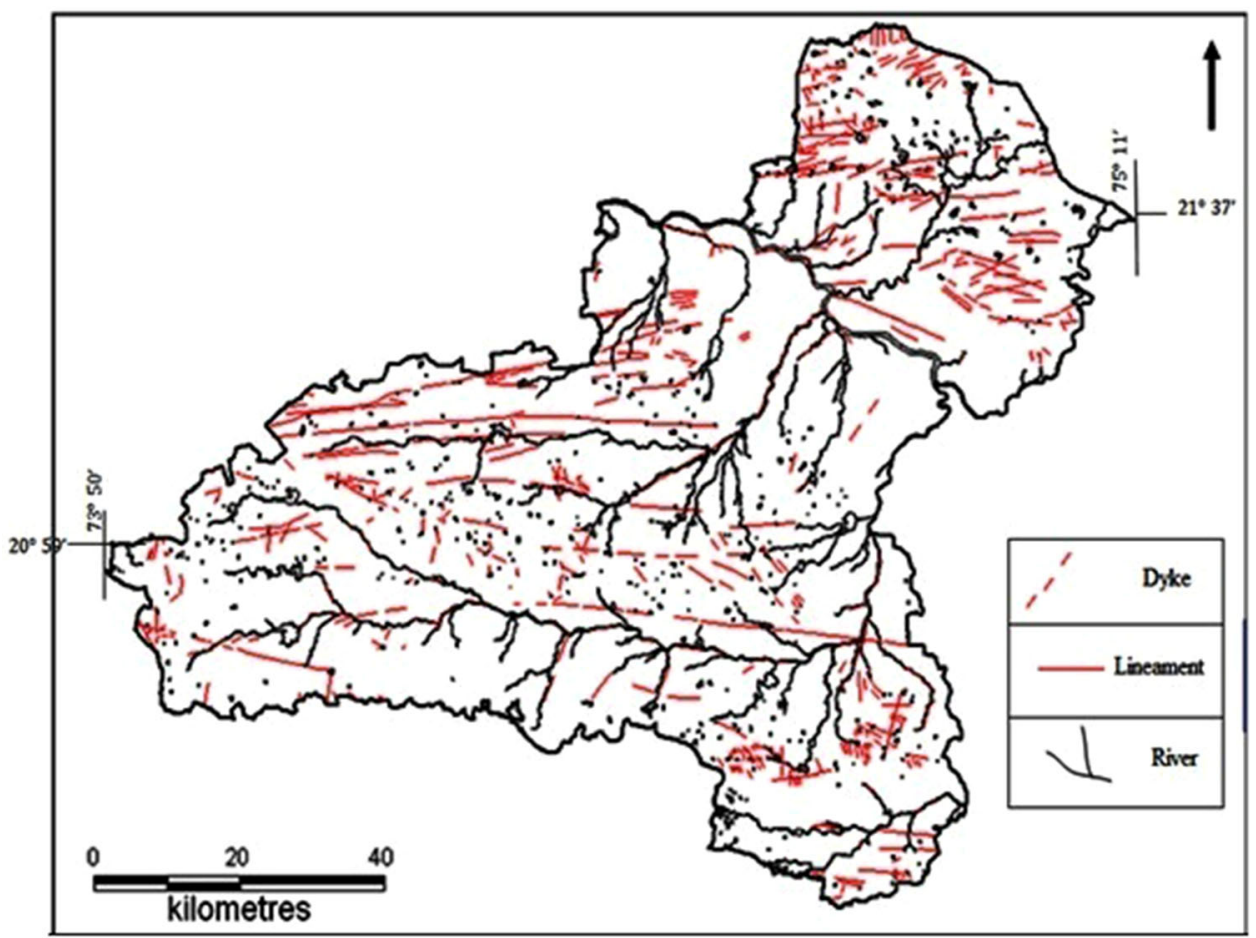

and occur in parts of Sakri and Dhule talukas. Medium type of soil is well suited for irrigation and cover parts of Sindhkheda, Sakri, and Dhule talukas. The weathered part of Deccan trap is called murum and covers a thickness of meter or $2 \mathrm{~m}$ between the soil and the lower hard rock.

Nearly, $75 \%$ of the total area of Shirpur taluka is covered by Tapi alluvium. This area is almost plain topographic expression with gentle slope towards south. The maximum thickness of this alluvium in Shirpur taluka is $65 \mathrm{~m}$. Similarly, northern portion of Sindhkheda taluka is also covered by Tapi alluvium which is saline with thickness $30-35 \mathrm{~m}$.

\section{Hydrogeology of the study area}

The well and bore-hole logs for Sakri taluka suggest that the upper layer consists of highly fractured basalt, a thin layer of soil/murum and highly weathered basalt, less fractured basalt, and compact basalt, but very thin layer of soil present in many of the sites is not reflected in the values obtained from VES. There are more dug wells present in this taluka. The water table is encountered at the depth of 10-12 $\mathrm{m}$ for dug wells and bore wells are rare because of the kind of lithology that does not support groundwater. However, few bore wells show the presence of water table at 100-120 m.

The general lithology in Shindkheda taluka shows a top layer of black cotton soil or soil. The thickness is less. It is followed by weathered basalt or murum, highly fractured basalt, weakly fractured basalt, and compact basalt. In this area, the groundwater is obtained from a depth of 16.5-18 $\mathrm{m}$ for dug wells. The dug wells over the period of time have become dry, and therefore, many farmers have taken bore in these wells (dug-cum-bore wells). The water is found at $137-152 \mathrm{~m}$. About $4000 \mathrm{~L} / \mathrm{h}$ is obtained.

The general lithology in Shirpur taluka is predominantly composed of alluvium. The bore-hole log shows upper layer of black cotton soil followed by sandy alluvium with clay lenses. Earlier, the water table was found at $27-30 \mathrm{~m}$ with sufficient water. Later on with time, the depth of water table increased. At present, it is tapped at $60-76 \mathrm{~m}$. The quantity of water is about $5000 \mathrm{~L} / \mathrm{h}$. It is observed that in Shindkheda, the groundwater was not available in sufficient quantity as compared to that of Shirpur. However, after incidents of Killari earthquake (September 1993), the situation has changed. Now, the Shindkheda taluka has a better quantity of water than Shirpur.

In Dhule taluka, the general lithology observed shows soil as the top layer with murum, jointed basalt, highly weathered and jointed basalt, weakly jointed basalt and compact basalt. There were more dug wells in the earlier times, but with lowering of the water table, the depth has increased, and therefore, bore holes are constructed. The water table encountered for dug wells is at $18-20 \mathrm{~m}$, and for bore wells, it is $137-152 \mathrm{~m}$ with $3000 \mathrm{~L} / \mathrm{h}$ quantity of water. 


\section{Methodology}

\section{Exploration techniques}

Geophysical methods were developed in the early 1900, and are still being used extensively for groundwater investigations by several workers who have also used the method for defining and delineating other structures and pollution. This method is considered as the most suitable for investigating geological structures. Das Balaram Maity and Tarafdar (2007) used a combination of resistivity-cum-IP sounding with Schlumberger and concluded that this can help to detect fluoride contamination (Todd 1959). Integrating groundwater data from electrical resistivity survey is employed using Wenner and Schlumberger electrode configuration to identify the subsurface features and location of water (Gurugnanam et al. 2008; Zohdy et al. 1974; Ayolabi 2005; Bhattacharya and Patra 1968; Deshpande 2008; Ojelabi et al. 2001; Alisiobi and Ako 2012; Ariyo et al. 2011; Patangay et al. 2002).

The resistivity survey is generally carried out across the slope, where conductivity varies with depth without lateral variation (Srinivasamoorthy et al. 2009). The application of resistivity is also used in coal and mineral exploration, but commonly, the method is used for groundwater exploration (Zohdy et al. 1974; Ayolabi 2005; Krishnamurthy et al. 2009; Kumar et al. 2011; Swartz 1937; Udaya Laxmi and Ramadass 2009). Studies on dykes have been carried out to classify the dykes as carrier or barrier for groundwater flow (Erram et al. 2010; Singh and Jamal 2002; GSDA 2001). Andrade (2011) and Golekar et al. (2014) have been established that VES method and 2D resistivity can be a better tool in understanding the hydro-geological problems (Andrade 2011; Golekar et al. 2014). In the area under study, electrical resistivity method is carried out and favorable groundwater zones are identified. It is now established fact that geophysical method gives a better information of subsurface geology.

The apparent resistivity using four probe electrodes configuration of Wenner and Schlumberger method is carried out on the same selected sites to observe the similarity and compared both the applications in terms of its use and handling in the field. The VES was carried out by Wenner and Schlumberger methods. For Wenner, data are plotted on respective graphs and values calculated. For Schlumberger, the IPI2 Win software was used. A total of 54 VES were carried out spread over the district and representing different lithological units (Table 1). The VES locations are shown in Fig. 3. The instrument used is resistivity meter MINITRONIX model AQUA II and AQUA II PLUS. In resistivity meter, AC voltage input is used $(100 / 200 \mathrm{~V})$.

\section{Wenner method (Wenner 1969)}

It is based on equal distance spacing 4 probe methods which is carried out by inverse slope method suggested by Narayan and Ramanujachary (1967). The objective of VES is to record the changes in resistivity with depth and to correlate it with the available geological information to infer the depths and resistivity of the layers present. The resistivity of the strata is determined by passing an electric current between two electrodes on the surface. As the distance between electrodes increases, the depth of penetration also increases. The penetration of current below the surface is proportional to $1 / 3$ rd distance between two current electrodes on the surface.

The resistivity meter is placed at the exploration site which is suitable for lateral spreading of the cable in either direction. The non polarizing electrodes needed for measuring the potential differences are placed at predetermined distances on either side of chosen center near to the measuring equipment. PVC covered cable is connected to the potential electrodes as also the current electrodes are connected to the proper terminals on the equipment. The power supply pack $(100 \mathrm{~V})$ is also connected to the instrument.

The current electrodes are driven into the ground $10 \mathrm{~cm}$ deep each on either side of the center. These current electrodes are connected to the instrument by PVC cable. The working of the instrument begins and is operated as per the principles used in the instrument. Current is passed through the two extreme electrodes; the potential difference measured between the two inner electrodes gives a measure of the resistivity of the ground. Due to its constant and extensive use, the Wenner's 4 probes method is used as this method provides a simple resistivity formula and the field procedure is easier.

In Wenner method, the array spacing "a" is increased by steps, keeping the midpoint fixed, the four electrodes with a definite array spacing "a" is moved as a whole in suitable steps, four electrodes are moving after each measurement, and the values from the instrument is recorded as $R$ with depth $d$. The reading $R$ is then divided by unit value to get the inverse values as $1 / R$.

Vertical electrical sounding (Wenner's method) carried out for 54 sites representing soil, weathered rock, and hard rock aquifers is presented in Table 1. The talukawise sample site distribution is 14 VES which were taken in Sakri taluka, 12 VES in Shindkheda taluka, 8 VES in Shirpur taluka, and 20 VES in Dhule taluka.

In the meantime, Narayan and Ramanujachary (1967) showed that it is possible to solve the field equation directly to get resistivity and thicknesses of the subsurface layers from the field data by inverse slope method (Narayan and 
Table 1 VES locations in Dhule district, India

\begin{tabular}{|c|c|c|c|c|c|c|c|c|}
\hline VES no. & Village & Taluka & VES no. & Village & Taluka & VES no. & Village & Taluka \\
\hline 1 & Nimgvhan & Sakri & 19 & Sulvade & Sindhkheda & 37 & Vinchur & Dhule \\
\hline 2 & Chinchkeda & Sakri & 20 & Sarve & Sindhkheda & 38 & Ankvadi & Dhule \\
\hline 3 & Kirvade & Sakri & 21 & Bhadne & Sindhkheda & 39 & Purmepada & Dhule \\
\hline 4 & Akkalpada & Sakri & 22 & Babhale & Sindhkheda & 40 & Mukti & Dhule \\
\hline 5 & Malpur & Sakri & 23 & Dattane & Sindhkheda & 41 & Kalkheda & Dhule \\
\hline 6 & Pimpalner & Sakri & 24 & Bamhane & Sindhkheda & 42 & Aarvi & Dhule \\
\hline 7 & Dahivel & Sakri & 25 & Pimprad & Sindhkheda & 43 & Ner & Dhule \\
\hline 8 & Varsus & Sakri & 26 & Chimthane & Sindhkheda & 44 & Junnar & Dhule \\
\hline 9 & Mhasdi & Sakri & 27 & Thalner & Shirpur & 45 & Tamsvadi & Dhule \\
\hline 10 & Surpan & Sakri & 28 & Manjrod & Shirpur & 46 & Nimgul & Dhule \\
\hline 11 & Sakri & Sakri & 29 & Kharde-Patharde & Shirpur & 47 & Babhulvadi & Dhule \\
\hline 12 & Chadvel-Korde & Sakri & 30 & Palasner & Shirpur & 48 & Kulthe & Dhule \\
\hline 13 & Kavthe & Sakri & 31 & Nimzari & Shirpur & 49 & Chaugaon & Dhule \\
\hline 14 & Perejpur & Sakri & 32 & Ahilyapur & Shirpur & 50 & Dhamangaon & Dhule \\
\hline 15 & Dhavde & Sindhkheda & 33 & Shirpur & Shirpur & 51 & Devbhane & Dhule \\
\hline 16 & Varshi & Sindhkheda & 34 & Vikharan & Shirpur & 52 & Khedi & Dhule \\
\hline 17 & Dondaicha & Sindhkheda & 35 & Borkund & Dhule & 53 & Morane & Dhule \\
\hline 18 & Dhamane & Sindhkheda & 36 & Nhyahalod & Dhule & 54 & Dhanur & Dhule \\
\hline
\end{tabular}

Fig. 3 VES location map along with geo-electric section and resistivity geo-electric section along NE-SW and NW-SE from Dhule district

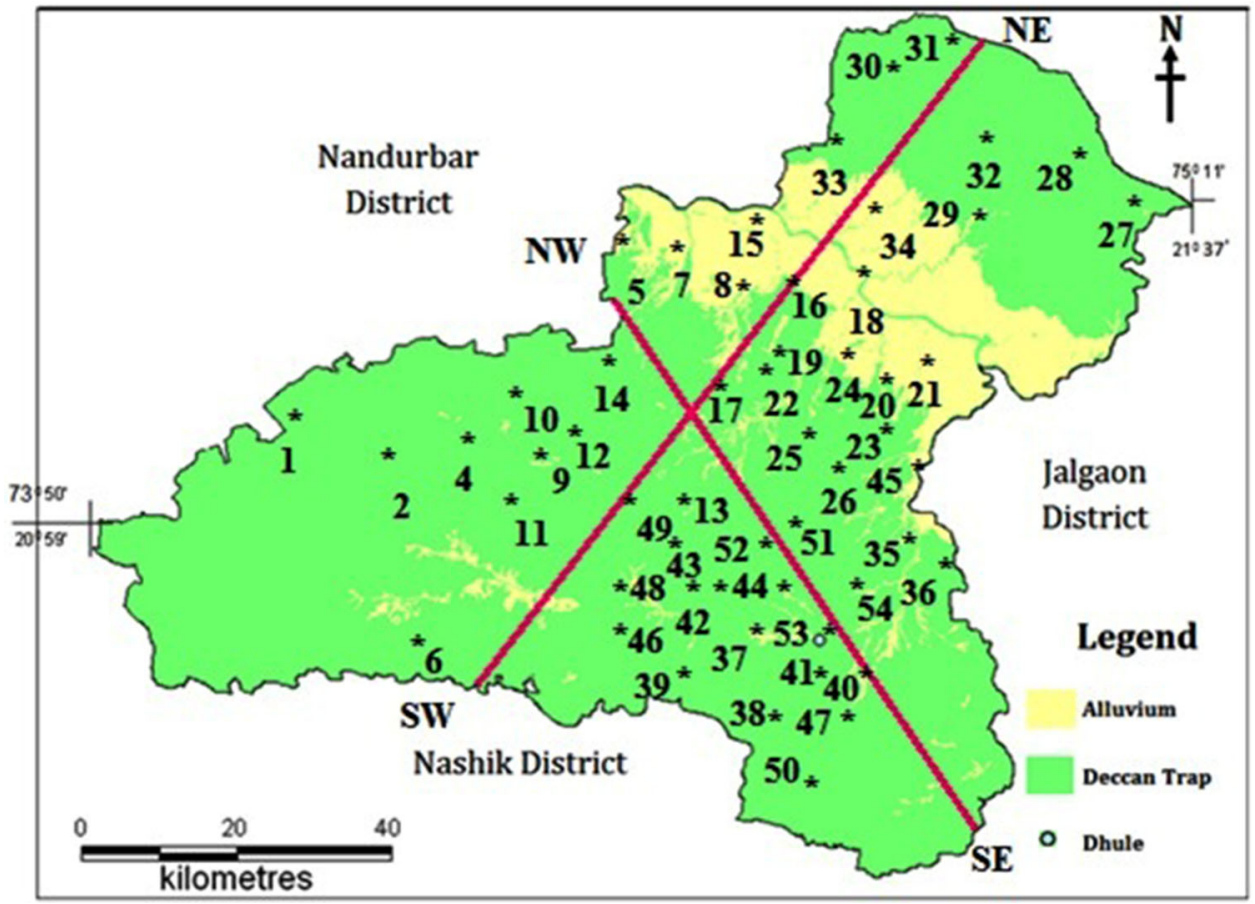

Ramanujachary 1967). The inverse slope vertical electrical resistivity (VES) method as suggested by these two authors works very well in engineering geology and also in groundwater exploration for 2-5 layered. This method assumes considerable importance in the field of groundwater exploration because of its ease of operation, low cost, and its capability. This method was tested widely in India, using it in different geological situations. It was found to give good results correlating well with bore-hole data. This method is simple and gives resistivities and depths directly from the plot of the field data on a linear graph. Interpretation by the inverse slope method has been used to 
calculate the values of $\frac{1}{R}$, where $R=\frac{V}{I}$ are plotted against the Wenner's electrode spacing.

The values of resistivity $p$ are determined by the formula, $\rho=\frac{V}{I} 2 \pi a$, where $V$ is the potential in volts measured between the two current electrodes, and $I$ is the current in amperes passes into the ground, and $a$ is the distance between the successive electrodes and $2 \pi$, a constant. Since $\frac{V}{I}=R$, the resistance (in ohms), the formula, may be expressed as: $p=2 \pi a R$., (in $\Omega \mathrm{m}$ ). The resistivity data were plotted in excel sheet, depth plotted on $X$ axis, and inverse $1 / R$ on $Y$ axis (Vaidyanadhan and Ramakrishnan 2008). The obtained resistivity value of each layer was compared with the standard values of different strata. Thereafter, a standard resistivity table prepared for the study area.

\section{Schlumberger method}

This method differs from Wenner arrangement in placing the two current electrodes with much larger interval than that between the two (inner) potential electrodes. Vertical electrical sounding (Schlumberger method) carried out for the same site, whereas VES was conducted through Wenner's method (Table 1). The obtained data from the instrument were key into the software for further calculations. The preliminary interpretation of the VES curves was carried out by the curve matching technique of Orellana and Mooney $(1972,1966)$ in which the field curves are matched with the theoretical master curve (Orellana and Mooney 1972, 1966). The VES curves plotted using the IPI2WIN Geoscientific Software (Babachev 1994).

Two-dimensional (2D) geo-electrical cross section has been drawn using the IPI2 win software along chosen profiles passing through different VES locations to understand the aquifer geometry in the study area.

\section{Result and discussion}

\section{Wenner method}

The generalized range of resistivity values for different litho units were proposed based on the resistivity sounding results which match with lithology of dug wells (Table 2). Figures 4, 5, 6, and 7 show talukawise representative inverse slope curve (Wenner's method) of Sakri, Shindkheda, Shirpur, and Dhule, respectively, regarding the present study area. The ranges of resistivity values of the subsurface strata obtained through Wenner method are presented in supplementary material (Appendix 1).

Type of aquifer, depth of water bearing rock formation, and suggested exploration of subsurface water through
Table 2 Ranges of resistivity values of different lithounits

\begin{tabular}{lll}
\hline Sr. no. & $\begin{array}{l}\text { Range of } \\
\text { resistivity }\end{array}$ & Lithounits \\
\hline 1 & $4-6 \Omega \mathrm{m}$ & Black cotton soil with sand \\
2 & $6-10 \Omega \mathrm{m}$ & Black cotton soil with calcified soil/murum \\
3 & $10-12 \Omega \mathrm{m}$ & Black cotton soil/murum \\
4 & $12-26 \Omega \mathrm{m}$ & Black cotton soil with murum \\
5 & $26-60 \Omega \mathrm{m}$ & Highly weathered and fractured basalt \\
6 & $60-100 \Omega \mathrm{m}$ & Highly fractured basalt \\
7 & $100-250 \Omega \mathrm{m}$ & Weakly fractured basalts \\
8 & $>250 \Omega \mathrm{m}$ & Hard compact basalts \\
\hline
\end{tabular}

In some occasion, black cotton soil may show higher resistivity due to the impervious nature (Zambre and Thigale 1980)

\section{VES 1}

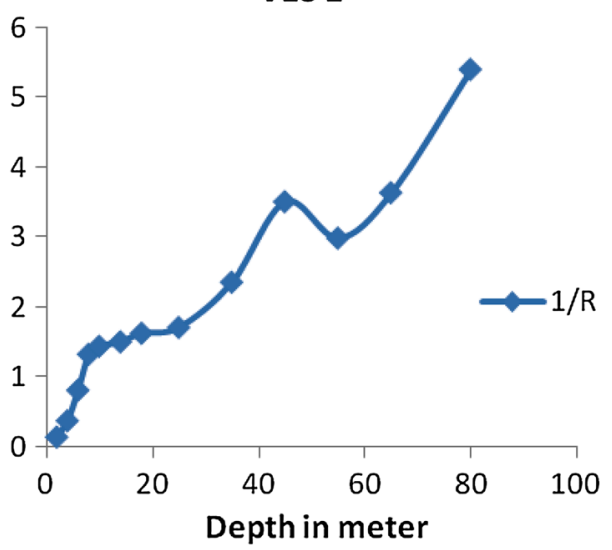

Fig. 4 Representative resistivity curve obtained by the inverse slope method from Sakri taluka

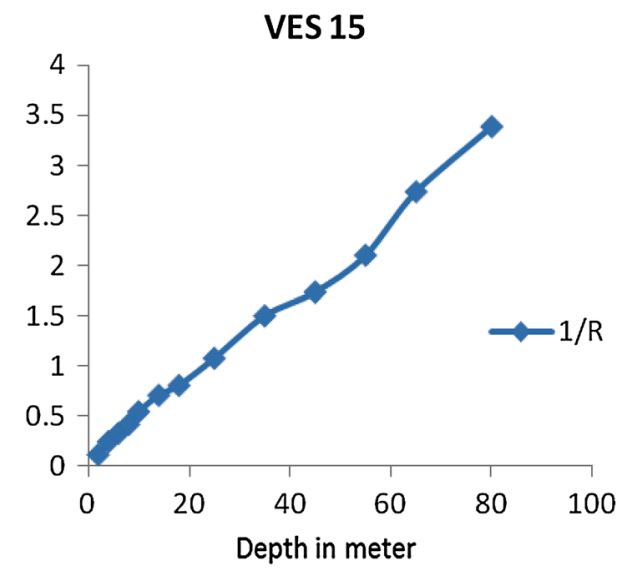

Fig. 5 Representative resistivity curve obtained by the inverse slope method from Shindkheda taluka

different types of wells are depicted in Table 3. However, certain points may be located, where there is a chance for occurrence of groundwater and feasibility for digging dug wells and bore wells. Based on the resistivity data, 37 sites 


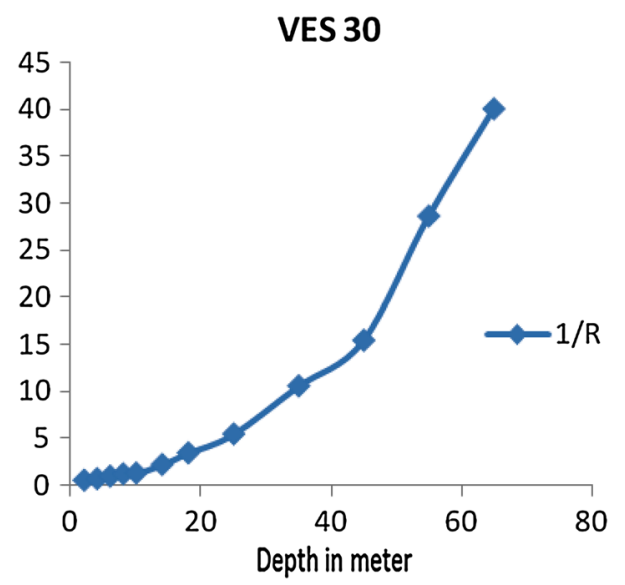

Fig. 6 Representative resistivity curve obtained by the inverse slope method from Shirpur taluka

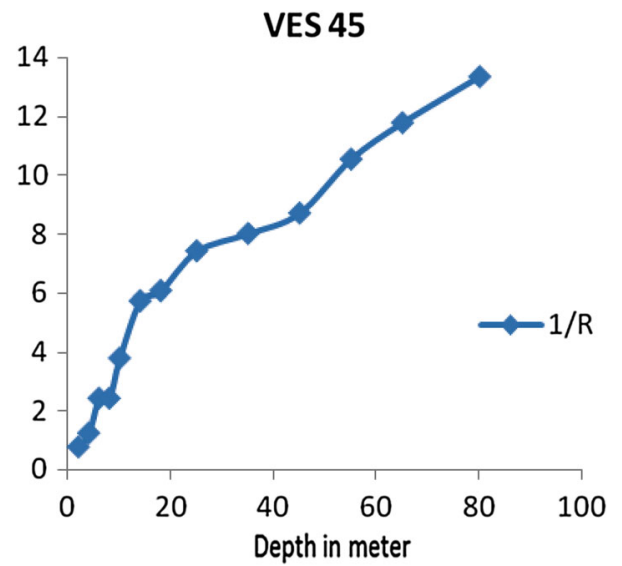

Fig. 7 Representative resistivity curve obtained by the inverse slope method from Dhule taluka

are feasible for exploration of dugwell out of 54 locations which have given a good indication of water bearing zones at shallow depth (Table 3). The remaining 17 sites are not feasible for the exploration of dugwell because of depth of water bearing rock formation at deep. Therefore, these sites are only suitable for exploration of bore wells. Resistivity result showed that the ten sites are suitable for exploration of bore wells and seven sites not feasible for exploration of borewell due to the presence of thick alluvium, hence these sites only suitable for drilling the tube wells (Table 3). Subsurface lithology indicates that the 43 sites belong to unconfined aquifer and 11 show under confined condition.

\section{Schlumberger method}

Figures $8,9,10$, and 11 indicate that talukawise sounding curves are interpreted as per Orellana and Mooney (Schlumberger method) for Sakri, Shindkheda, Shirpur, and Dhule, respectively, regarding the present study area.
Resistivity values and thickness of different layers at all VES locations from Dhule district are presented Table 4. The Schlumberger sounding data are used for creating comprehensive pictures on horizontal scale along two different sections such as NW-SE and NE-SW over the Dhule district. NW-SE passing through VES 6, 12, 11, 17, 16,33 , and $31 \mathrm{NW}-\mathrm{SE}$ trends covered near about $90 \mathrm{~km}$. NE-SW passing through VES 5, 17, 40, and 53 NE-SW trends covered near about $75 \mathrm{~km}$.

\section{Pseudo cross sections}

Figures 12 show the pseudo cross sections of VES 6, 12, $11,17,16,33$, and 31 in the study area. In Fig. 12, at VES 11 , the feasible zone is from 9.0 to $14 \mathrm{~m}$ (shallow aquifer) and 26 to $37 \mathrm{~m}$ (deep aquifer) indicating highly weathered and fractured basalts, while, at VES 16, 33, and 31, anomaly constantly increasing $(<13.3-100 \Omega \mathrm{m})$. This indicates a sudden change from black cotton soil, highly weathered and fractured basalts, and weakly fractured basalts to hard and compact basalts, which are less productive from groundwater point of view. Figures 13 show the pseudo cross sections of VES 5, 17, 40, and 55 in the study area. In Fig. 13, all VES stations show that the resistivity anomaly constantly increased. This indicates a sudden change from black cotton soil, highly weathered and fractured, highly fractured basalts, and weakly fractured basalts to hard and compact basalts, which are less productive from groundwater point of view.

\section{Resistivity cross sections}

The geo-electrical section along NW-SE includes sites VES 6, 12, 11, 17, 16, 33, and 31 (Fig. 12). The geoelectrical section along NE-SW includes sites VES 5, 17, 40, and 53 (Fig. 13). In Fig. 12, at VES 6 below soil layer, resistivity trend increases up to $360 \Omega \mathrm{m}$ indicative of hard and massive basaltic layer. At VES, 12 increases resistivity with increasing depth indicating poor aquifer zone. Afterward, below VES 11, resistivity anomaly abruptly decreases with increasing depth $0.362 \Omega \mathrm{m}$ (30 $\mathrm{m}$ below) and may serve as groundwater potential zone. At VES 16 and 33 below soil layer, resistivity anomaly decreases downward up to 95 and $11.4 \Omega \mathrm{m}$ suggestive of highly fractured basalt and highly weathered and fractured basalt, respectively. At VES 31, trend first increases $(6648 \Omega \mathrm{m})$ and then gradually decreases $(249 \Omega \mathrm{m})$ exhibiting hard compact basalts and weakly fractured basalts, respectively. This indicates less productive zone of groundwater.

In Fig. 13, at all VES in this cross section, resistivity trend is very less at the top $(<2 \Omega \mathrm{m})$. Then, below VES 5, resistivity anomaly increases up to $129-423 \Omega \mathrm{m}$ and this 
Table 3 Type of aquifer, depth of water bearing rock formation, and recommendation for exploration through wells

\begin{tabular}{|c|c|c|c|c|}
\hline VES & $\begin{array}{l}\text { Depth of favorable water } \\
\text { bearing rock formation }\end{array}$ & Yield & Type of aquifer & $\begin{array}{l}\text { Recommendation for } \\
\text { exploration through wells }\end{array}$ \\
\hline 1 & $35-45 \mathrm{~m}$ & Medium & Unconfined & Bore well \\
\hline 2 & $10-14 \mathrm{~m}$ & Medium & Unconfined & Dug well \\
\hline 3 & $14-18 \mathrm{~m}$ & Medium & Confined & Dug well \\
\hline 4 & $6-16 \mathrm{~m}$ & High & Unconfined & Dug well \\
\hline 5 & Below $18 \mathrm{~m}$ & High & Unconfined & Dug well \\
\hline 6 & $18-25 \mathrm{~m}$ & Low & Confined & Dug well \\
\hline 7 & Below 35 & Medium & Unconfined & Bore well \\
\hline 8 & 14-18 m & Medium & Confined & Dug well \\
\hline 9 & $4-14 \mathrm{~m}$ & High & Unconfined & Dug well \\
\hline 10 & $55-80 \mathrm{~m}$ & Low & Unconfined & Bore well \\
\hline 11 & $4-25 \mathrm{~m}$ & High & Unconfined & Dug well \\
\hline 12 & Up to $10 \mathrm{~m}$ & Low & Unconfined & Dug well \\
\hline 13 & Up to $6 \mathrm{~m} ; 25-65 \mathrm{~m}$ & Medium & Unconfined & Dug well \\
\hline 14 & $6-18 \mathrm{~m}$ & Medium & Confined & Dug well \\
\hline 15 & $55-65 \mathrm{~m}$ & Medium & Unconfined & Bore well \\
\hline 16 & $45-55 \mathrm{~m}$ & Medium & Unconfined & Bore well \\
\hline 17 & Up to $18 \mathrm{~m}$ & Medium & Unconfined & Dug well \\
\hline 18 & $25-55 \mathrm{~m}$ & Medium & Unconfined & Bore well \\
\hline 19 & $10-18 \mathrm{~m}$ & Medium & Unconfined & Dug well \\
\hline 20 & $10-18 \mathrm{~m}$ & Medium & Unconfined & Dug well \\
\hline 21 & $35-45 \mathrm{~m}$ & Medium & Confined & Bore well \\
\hline 22 & $10-18 \mathrm{~m}$ & High & Unconfined & Dug well \\
\hline 23 & $10-25 \mathrm{~m}$ & Medium & Confined & Dug well \\
\hline 24 & Below $4 \mathrm{~m}$ & High & Unconfined & Dug well \\
\hline 25 & $6-18 \mathrm{~m}$ & Medium & Unconfined & Dug well \\
\hline 26 & $14-18 \mathrm{~m}$ and below $18 \mathrm{~m}$ & Medium & Confined & Dug well \\
\hline 27 & $65-80 \mathrm{~m}$ & Medium & Unconfined & Tube well \\
\hline 28 & $45-80 \mathrm{~m}$ & Medium & Unconfined & Tube well \\
\hline 29 & $55-65 \mathrm{~m}$ & Medium & Unconfined & Tube well \\
\hline 30 & $45-65 \mathrm{~m}$ & Medium & Unconfined & Tube well \\
\hline 31 & $45-80 \mathrm{~m}$ & Medium & Unconfined & Tube well \\
\hline 32 & $55-70 \mathrm{~m}$ & Medium & Unconfined & Tube well \\
\hline 33 & $35-45 \mathrm{~m}$ & Medium & Unconfined & Tube well \\
\hline 34 & Below $35 \mathrm{~m}$ & Medium & Unconfined & Bore well \\
\hline 35 & Below 4 m & Medium & Unconfined & Dug well \\
\hline 36 & Up to $25 \mathrm{~m}$ & Medium & Unconfined & Dug well \\
\hline 37 & $8-14 \mathrm{~m}$ & Low & Unconfined & Dug well \\
\hline 38 & $4-14 \mathrm{~m}$ & Low & Unconfined & Dug well \\
\hline 39 & $23-33 \mathrm{~m}$ and below $43 \mathrm{~m}$ & Medium & Unconfined & Bore well \\
\hline 40 & $6-11 \mathrm{~m} ; 25-55 \mathrm{~m}$ and below $55 \mathrm{~m}$ & Low & Confined & Bore well \\
\hline 41 & Up to $08 \mathrm{~m}$ & Low & Confined & Dug well \\
\hline 42 & $10-18 \mathrm{~m}$ & High & Confined & Dug well \\
\hline 43 & $10-18 \mathrm{~m}$ & Medium & Unconfined & Dug well \\
\hline 44 & $6-8 \mathrm{~m}$ & Low & Unconfined & Dug well \\
\hline 45 & Below 14 m & High & Unconfined & Dug well \\
\hline 46 & Below 45 m & Medium & Unconfined & Bore well \\
\hline 47 & $4-6 \mathrm{~m}$ and $8-10 \mathrm{~m}$ & Medium & Unconfined & Dug well \\
\hline 48 & $18-25 \mathrm{~m}$ & Medium & Unconfined & Dug well \\
\hline
\end{tabular}


Table 3 continued

\begin{tabular}{lllll}
\hline VES & $\begin{array}{l}\text { Depth of favorable water } \\
\text { bearing rock formation }\end{array}$ & Yield & Type of aquifer & $\begin{array}{l}\text { Recommendation for } \\
\text { exploration through wells }\end{array}$ \\
\hline 49 & Below $4 \mathrm{~m}$ & High & Unconfined & Dug well \\
50 & $25-35 ; 45-65 \mathrm{~m}$ & Medium & Unconfined & Bore well \\
51 & $18-25 \mathrm{~m}$ and $45-65 \mathrm{~m}$ & Low & Confined & Bore well \\
52 & Below $10 \mathrm{~m}$ & High & Unconfined & Dug well \\
53 & $6-25 \mathrm{~m}$ & High & Unconfined & Dug well \\
54 & $8-15 \mathrm{~m}$ & High & Confined & Dug well \\
\hline
\end{tabular}

Fig. 8 Representative sounding curves are interpreted as per Orellana and Mooney by Schlumberger methods from Sakri taluka

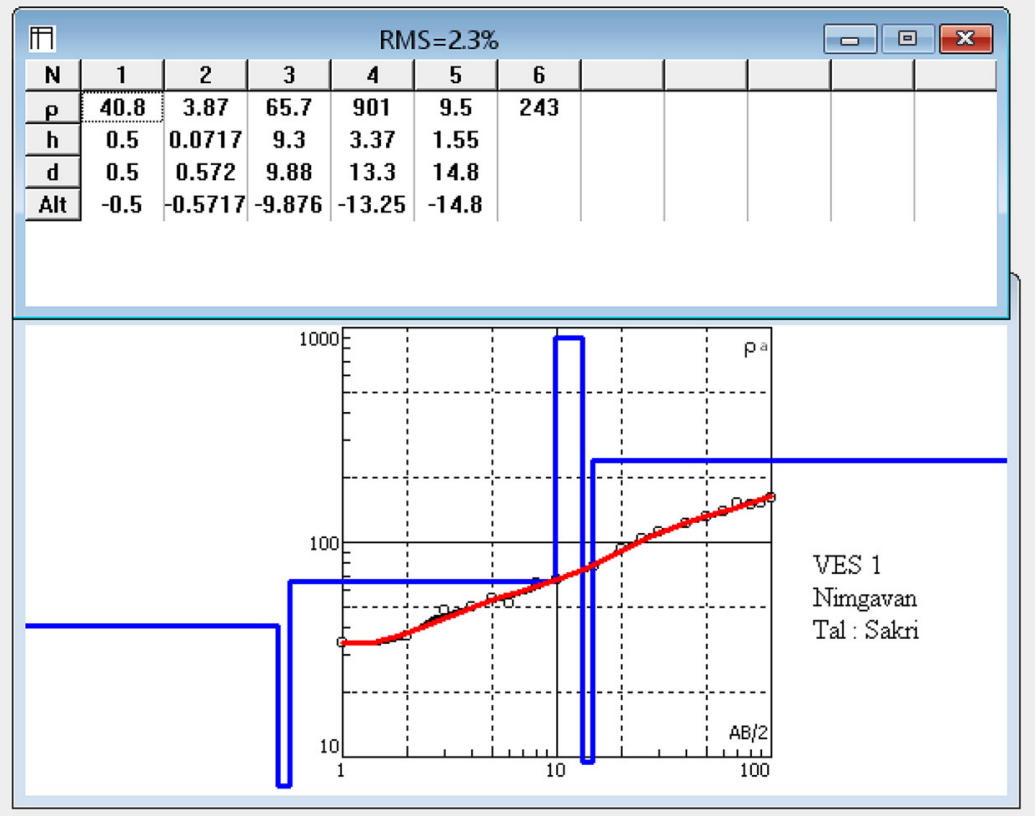

indicates the presence of weakly fractured basalts and hard compact basalt. However, at VES 17, ascending downward trend gradually increases from 18 to $30 \Omega \mathrm{m}$ suggesting highly weathered or fractured basalts, and again, resistivity decreases up to $10 \Omega \mathrm{m}$. At VES 40, below soil layer, trend of resistivity increases up to $181 \Omega \mathrm{m}$. This indicates the presence of weakly fractured basalts below $2 \mathrm{~m}$. At VES 53 , resistivity increases from 18 to $<30 \Omega \mathrm{m}$, becoming 1-10 $\Omega \mathrm{m}$ and suggesting highly weathered/fractured jointed basalts. This indicates good aquifer zone between 1 and $5 \mathrm{~m}$ (shallow aquifer).

This suggests that the groundwater potential is more along the highly fractured rocks and in alluvium. The central part of the district can be considered to be potential zone for groundwater. This indicates that Sakri and Dhule taluka are prone to drought conditions in terms of availability of groundwater zone. The data corroborate with the observations of central groundwater board.

\section{Curves types (Schlumberger method)}

The resistivity curve types $\mathrm{A}, \mathrm{Q}, \mathrm{H}$, and $\mathrm{K}$ and combinations were obtained. These curves are interpreted using the curve matching technique using two and three layer master curves (Singh and Tripathi 2009). The different basic types of curves are $\mathrm{Q}$ type $(\rho 1>\rho 2>\rho 3), \mathrm{H}$ type $(\rho 1>\rho 2<\rho 3)$, $\mathrm{K}$ type $(\rho 1<\rho 2>\rho 3)$, and $\mathrm{A}$ type $(\rho 1<\rho 2<\rho 3)$. A combination of the basic curves can be obtained if the model is obtained for more than three layers. Then, the combinations possible can be as HA type $(\rho 1>\rho 2<\rho 3<\rho 4)$, HK type $(\rho 1>\rho 2<\rho 3>\rho 4)$, AA type $(\rho 1<\rho 2<\rho 3<\rho 4)$, AK type $(\rho 1<\rho 2<\rho 3>\rho 4)$, KH type $(\rho 1<\rho 2>\rho 3<\rho 4)$, KQ type $(\rho 1<\rho 2>$ $\rho 3>\rho 4)$, QH type $(\rho 1>\rho 2>\rho 3<\rho 4)$, and QQ type $(\rho 1>\rho 2>\rho 3>\rho 4)$.

In the study area, 5-6 layer model is obtained, and therefore, the curve types are identified accordingly in 
Fig. 9 Representative sounding curves are interpreted as per Orellana and Mooney by

Schlumberger methods from

Sindhkheda taluka

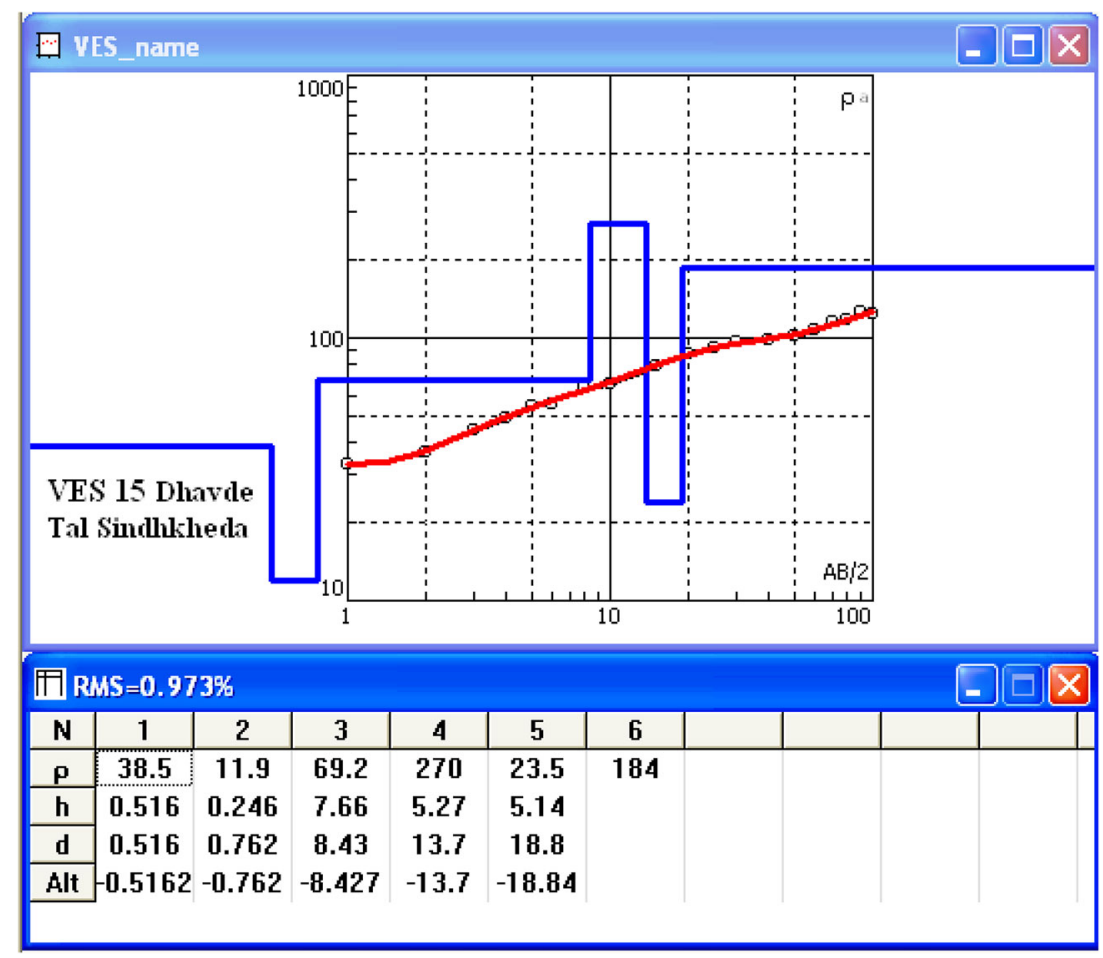

Fig. 10 Representative sounding curves are interpreted as per Orellana and Mooney by Schlumberger methods from Shirpur taluka

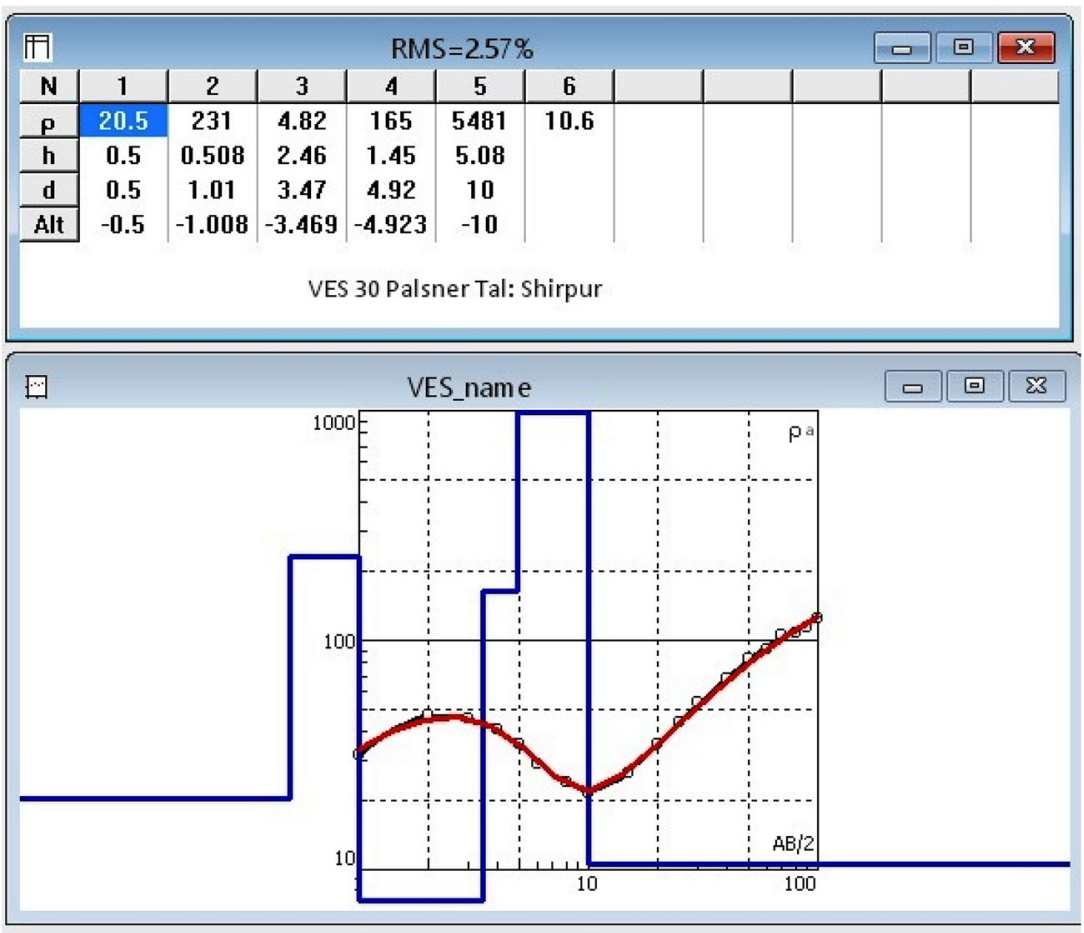

combinations with the basic types. The majority of the curve types observed in the area under study are as follows:

For Sakri taluka, the majority of curve types are $\mathrm{HKH}=\mathrm{AKH}>\mathrm{KHA}$.
The Shindkheda taluka shows the majority of curve types are $\mathrm{KHA}>\mathrm{HAK}>\mathrm{KHK}$;

In Shirpur taluka, the majority of curve types are $\mathrm{KHA}>\mathrm{KQH}=\mathrm{KQH}$; 
Fig. 11 Representative sounding curves are interpreted as per Orellana and Mooney by Schlumberger methods from Dhule taluka

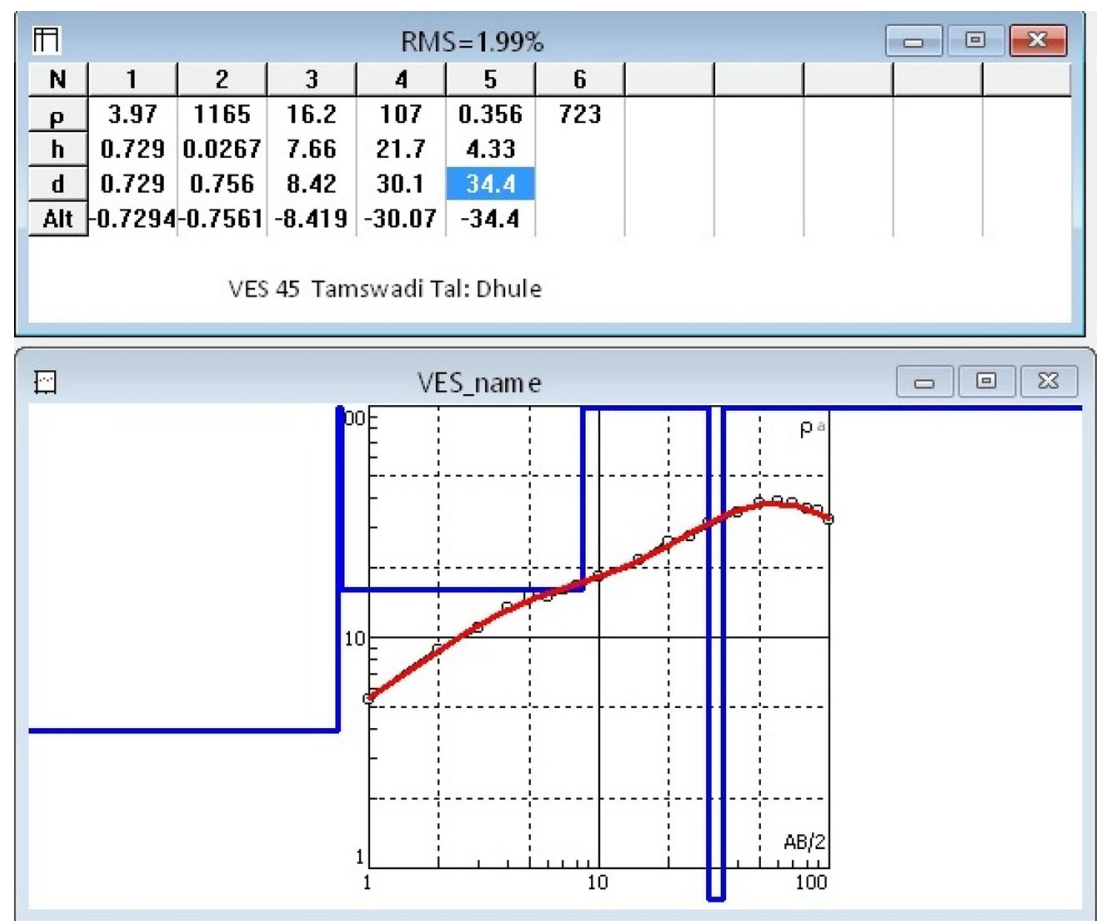

For Dhule taluka, the majority of curve types are $\mathrm{HKH}>\mathrm{KHK}>\mathrm{HAK}$.

\section{Talukawise lithological interpretations based on layers obtained as a result of Schlumberger method}

\section{Sakri taluka}

First layer It is observed that resistivity range varies from 4.23 to $114 \Omega \mathrm{m}$. The value more than $100 \Omega \mathrm{m}$ is observed in VES no. 9 which is weakly fractured to hard compact basalt. The values between 10 and $100 \Omega \mathrm{m}$ are observed in VES no. 1, 2, 3, 4, 5, 6, 7, 10, 11, 12, and 14 which shows the presence of highly weathered basalts. The values less than $10 \Omega \mathrm{m}$ are observed in VES no. 8 and 13 with weathered basalts or murum/black cotton soil. Thickness varies from 0.5 to $1.56 \mathrm{~m}$.

Second layer The resistivity range varies from 3.87 to $665 \Omega \mathrm{m}$. The value of resistance is more than $100 \Omega \mathrm{m}$ which was observed in VES no. 3, 5, 12, and 13 which is weakly fractured to hard compact basalts. The values between 10 and $100 \Omega \mathrm{m}$ are observed in VES no. 4, 7, 8, $9,10,11$, and 14 which suggest highly weathered basalts. The resistance values less than $10 \Omega \mathrm{m}$ are observed in VES no. 1, 2, and 6 which indicate the presence of weathered basalts or black cotton soil/murum. Thickness varies from 0.0717 to $11 \mathrm{~m}$.

Third layer $\quad$ It varies from 10.9 to $3027 \Omega \mathrm{m}$. The values more than $100 \Omega \mathrm{m}$ are observed in VES no. 1, 3, 4, 6, 7, 8, and 10. The layer is weakly fractured to hard compact basalts. The values between 10 and $100 \Omega \mathrm{m}$ are observed in VES no. 2, 5, 9, 11, 12, 13, and 14 which shows the presence of highly weathered basalts. Thickness varies from 0.0698 to $11.1 \mathrm{~m}$.

Fourth layer The range varies between 0.498 and $2627 \Omega \mathrm{m}$. The value more than $100 \Omega \mathrm{m}$ is observed in VES no. $2,5,12,13$, and 14 which is weakly fractured to hard compact basalts. The values between 10 and $100 \Omega \mathrm{m}$ are observed in VES no. 1, 3, 6,7, 8, 9, and 11 which are highly weathered basalts and less than $10 \Omega \mathrm{m}$ are observed in VES no. 4 and 10 which show weathered basalts or black cotton soil/murum. Thickness varies from 0.307 to $45.2 \mathrm{~m}$.

Fifth layer The range varies between 8.66 and $1458 \Omega \mathrm{m}$. The value more than $100 \Omega \mathrm{m}$ is observed in VES no. 1, 3, $4,5,67,8,9$, and 12 which is weakly fractured to hard compact basalts. The values between 10 and $100 \Omega \mathrm{m}$ are observed in VES no. 13 and 14 which show that the presence of highly weathered basalts and values less than $10 \Omega \mathrm{m}$ are observed in VES no. 2 and 11 showing 
Table 4 Resistivity values and thickness of different layers at all VES locations from Dhule district (Schlumberger method)

\begin{tabular}{|c|c|c|c|c|c|c|c|c|c|c|c|c|}
\hline VES no. & $p 1$ & $p 2$ & p3 & $p 4$ & $p 5$ & $p 6$ & $h 1$ & $h 2$ & $h 3$ & $h 4$ & $h 5$ & Type curve \\
\hline 1 & 40.8 & 3.87 & 65.7 & 901 & 9.5 & 243 & 0.5 & 0.0717 & 9.3 & 3.37 & 1.55 & HAK \\
\hline 2 & 52.3 & 8.43 & 134 & 24 & 111 & 16.2 & 0.68 & 0.258 & 0.49 & 1.09 & 88.9 & HKH \\
\hline 3 & 61.6 & 107 & 1048 & 86.3 & 10,401 & - & 0.935 & 2.16 & 4.57 & 45.2 & - & $\mathrm{AKH}$ \\
\hline 4 & 29.7 & 28.5 & 3027 & 1.73 & 148 & 3.62 & 0.849 & 0.987 & 0.0698 & 0.307 & 97.4 & HKH \\
\hline 5 & 25.5 & 220 & 18 & 196 & 413 & 1530 & 0.5 & 0.425 & 0.577 & 16.3 & 82.2 & KHA \\
\hline 6 & 35.9 & 8.44 & 188 & 36.4 & 134 & 387 & 0.545 & 0.118 & 0.307 & 0.778 & 15.7 & $\mathrm{HKH}$ \\
\hline 7 & 36.4 & 46.2 & 378 & 87 & 1458 & 95.8 & 0.5 & 3.79 & 0.0748 & 16.2 & 6.03 & $\mathrm{AKH}$ \\
\hline 8 & 5.46 & 29.6 & 213 & 48.6 & 153 & 130 & 0.5 & 0.836 & 2.23 & 5.96 & 15.9 & $\mathrm{AKH}$ \\
\hline 9 & 114 & 45.9 & 11.8 & 36.3 & 368 & 35.4 & 0.5 & 1.61 & 0.529 & 16.8 & 8.12 & QHA \\
\hline 10 & 46.2 & 22.7 & 228 & 0.498 & - & - & 1.33 & 11 & 11.1 & - & - & HK \\
\hline 11 & 43.2 & 26.2 & 69.9 & 28.7 & 8.66 & 222 & 0.553 & 0.624 & 0.707 & 8.6 & 7.45 & HKQ \\
\hline 12 & 42.8 & 127 & 50.2 & 106 & 229 & 16.5 & 1.56 & 0.21 & 6.15 & 31.5 & 42.1 & KHA \\
\hline 13 & 4.23 & 665 & 18.8 & 2627 & 21.3 & 1307 & 0.5 & 0.385 & 2.34 & 3.19 & 10.3 & KHK \\
\hline 14 & 32.5 & 22.4 & 10.9 & 528 & 52.2 & 3155 & 0.5 & 2.33 & 2.09 & 0.571 & 55.4 & QHK \\
\hline 15 & 38.5 & 11.9 & 69.2 & 270 & 23.5 & 184 & 0.516 & 0.246 & 7.66 & 5.27 & 5.14 & HAK \\
\hline 16 & 52.8 & 4.05 & 134 & 725 & 13 & 101 & 0.968 & 0.639 & 0.399 & 2.54 & 2.29 & HAK \\
\hline 17 & 28.7 & 30 & 28 & 30.9 & 148 & 46.6 & 0.882 & 2.25 & 2.54 & 29.5 & 22.3 & KHA \\
\hline 18 & 23.7 & 3.53 & 76.3 & 10.5 & 71.4 & 5995 & 0.513 & 0.455 & 0.198 & 9.62 & 53 & HKH \\
\hline 19 & 51.1 & 214 & 27.7 & 565 & 194 & 11 & 0.96 & 0.848 & 1.38 & 1.2 & 78.6 & KHK \\
\hline 20 & 38.4 & 5.09 & 29.6 & 724 & 35.8 & 8.14 & 0.618 & 0.109 & 8.16 & 24 & 35.1 & HAK \\
\hline 21 & 51.1 & 214 & 27.7 & 565 & 194 & 11 & 0.96 & 0.848 & 1.38 & 1.2 & 78.6 & KHK \\
\hline 22 & 16.3 & 46.7 & 426 & 600 & 11.9 & 1.82 & 0.5 & 2.03 & 28 & 11.8 & 15 & AAK \\
\hline 23 & 17.9 & 151 & 12 & 114 & 997 & 2.62 & 0.6 & 0.652 & 0.409 & 18.6 & 18.3 & КНА \\
\hline 24 & 14 & 477 & 8.56 & 218 & 7186 & 26.4 & 0.5 & 0.252 & 0.978 & 19.3 & 3.01 & КНА \\
\hline 25 & 23.2 & 56.8 & 15.7 & 66.6 & 11,156 & 9.55 & 1.25 & 8.427 & 4.05 & 11.3 & 1.22 & КНА \\
\hline 26 & 18.4 & 10.3 & 32.6 & 86.9 & 412 & 3.17 & 0.501 & 0.14 & 2.08 & 23.9 & 12.1 & HAA \\
\hline 27 & 2.9 & 172 & 0.347 & 8.47 & 133 & 1.1 & 0.5 & 0.396 & 0.0799 & 22.1 & 11.7 & $\mathrm{KQH}$ \\
\hline 28 & 22.9 & 9.91 & 1.92 & 6.79 & 266 & 2.03 & 0.5 & 2.8 & 0.633 & 21.6 & 8.23 & QHA \\
\hline 29 & 8.76 & 196 & 3.17 & 1077 & 11,317 & 44.1 & 0.5 & 0.326 & 1.62 & 7.09 & 72.5 & КНА \\
\hline 30 & 20.5 & 231 & 4.82 & 165 & 5481 & 10.6 & 0.5 & 0.508 & 2.46 & 1.45 & 5.08 & КHA \\
\hline 31 & 3.27 & 57.1 & 2.2 & 287 & 6648 & 249 & 0.503 & 678 & 2.19 & 4.62 & 74 & КНА \\
\hline 32 & 23.1 & 9.43 & 1.74 & 6.85 & 281 & 2.03 & 0.5 & 2.98 & 0.618 & 20.9 & 7.42 & QHA \\
\hline 33 & 4.83 & 71.9 & 2.09 & 180 & 7217 & 11.4 & 0.571 & 0.564 & 1.95 & 1.11 & 3.22 & KHA \\
\hline 34 & 19.8 & 114 & 20.2 & 3.02 & 17.6 & - & 0.953 & 0.277 & 9.98 & 2.36 & - & $\mathrm{KQH}$ \\
\hline 35 & 19.8 & 12.5 & 155 & 25.5 & 162 & 6.56 & 0.738 & 0.496 & 1.1 & 3.48 & 72 & $\mathrm{HKH}$ \\
\hline 36 & 18.1 & 1.15 & 352 & 5.24 & 68,230 & 18.1 & 0.54 & 0.156 & 0.659 & 4.53 & 0.441 & HKH \\
\hline 37 & 118 & 9.57 & 134 & 150 & 2572 & 2.99 & 0.521 & 0.157 & 6.36 & 0.402 & 7.8 & HAA \\
\hline 38 & 144 & 108 & 2167 & 323 & 224 & 6.28 & 0.507 & 0.536 & 0.169 & 26.6 & 41 & HKQ \\
\hline 39 & 64.1 & 2.98 & 1031 & 16.8 & 2143 & 200 & 0.5 & 0.106 & 0.34 & 3.05 & 2.51 & $\mathrm{HKH}$ \\
\hline 40 & 27.5 & 522 & 28.7 & 181 & 932 & - & 0.645 & 0.848 & 0.407 & 98.1 & - & КHA \\
\hline 41 & 35 & 3.62 & 124 & 248 & 41.7 & 2927 & 0.5 & 0.0686 & 14.3 & 9.84 & 22.3 & HAK \\
\hline 42 & 5.86 & 19.6 & 10.4 & 1424 & 5.09 & 0.957 & 1.81 & 0.164 & 0.607 & 4.93 & 17.9 & KHK \\
\hline 43 & 116 & 138 & 578 & 80.9 & 190 & 302 & 0.508 & 3.38 & 4.5 & 11.8 & 17 & $\mathrm{AKH}$ \\
\hline 44 & 173 & 706 & 79 & 2040 & 8.54 & 723 & 2.02 & 0.944 & 2.08 & 9.61 & 6.93 & KHK \\
\hline 45 & 3.97 & 1165 & 16.2 & 107 & 0.356 & 723 & 0.729 & 0.0267 & 7.66 & 21.7 & 4.33 & KHK \\
\hline 46 & 12.4 & 78.1 & 16.2 & 63.4 & 2.79 & 723 & 0.729 & 0.0266 & 1.73 & 29.6 & 1.66 & KHK \\
\hline 47 & 355 & 115 & 390 & 27.5 & 497 & 0.916 & 0.517 & 7.34 & 3.01 & 7.38 & 12.2 & $\mathrm{HKH}$ \\
\hline 48 & 5.55 & 67.3 & 5.6 & 34 & 1103 & 0.916 & 1.08 & 0.7448 & 2.49 & 7.88 & 4.08 & KHA \\
\hline
\end{tabular}


Table 4 continued

\begin{tabular}{llllllllllllll}
\hline VES no. & $p 1$ & $p 2$ & $p 3$ & $p 4$ & $p 5$ & $p 6$ & $h 1$ & $h 2$ & $h 3$ & $h 4$ & $h 5$ & Type curve \\
\hline 49 & 15.5 & 0.755 & 5701 & 1455 & 5.55 & 0.916 & 0.5 & 0.249 & 0.368 & 3.25 & 61.9 & HKQ \\
50 & 299 & 3.84 & 3719 & 42.9 & 190 & 0.916 & 0.706 & 0.19 & 0.177 & 3.3 & 95.6 & HKH \\
51 & 243 & 1.87 & 6606 & 23.8 & 484 & 0.916 & 0.5 & 0.138 & 0.102 & 3.16 & 42.4 & HKH \\
52 & 6.47 & 3.29 & 184 & 675 & 145 & 19.7 & 0.875 & 0.0635 & 3.94 & 0.392 & 94.7 & HAK \\
53 & 7.5 & 0.582 & 29.1 & 151 & 177 & 19.7 & 0.875 & 0.0448 & 3.96 & 0.392 & 94.7 & HAA \\
54 & 12.3 & 451 & 16.2 & 4859 & 88.8 & 12 & 0.875 & 0.0296 & 3.71 & 0.198 & 92.9 & KHK \\
\hline
\end{tabular}

$h$ thickness (meter); $p$ resistivity $(\Omega \mathrm{m})$

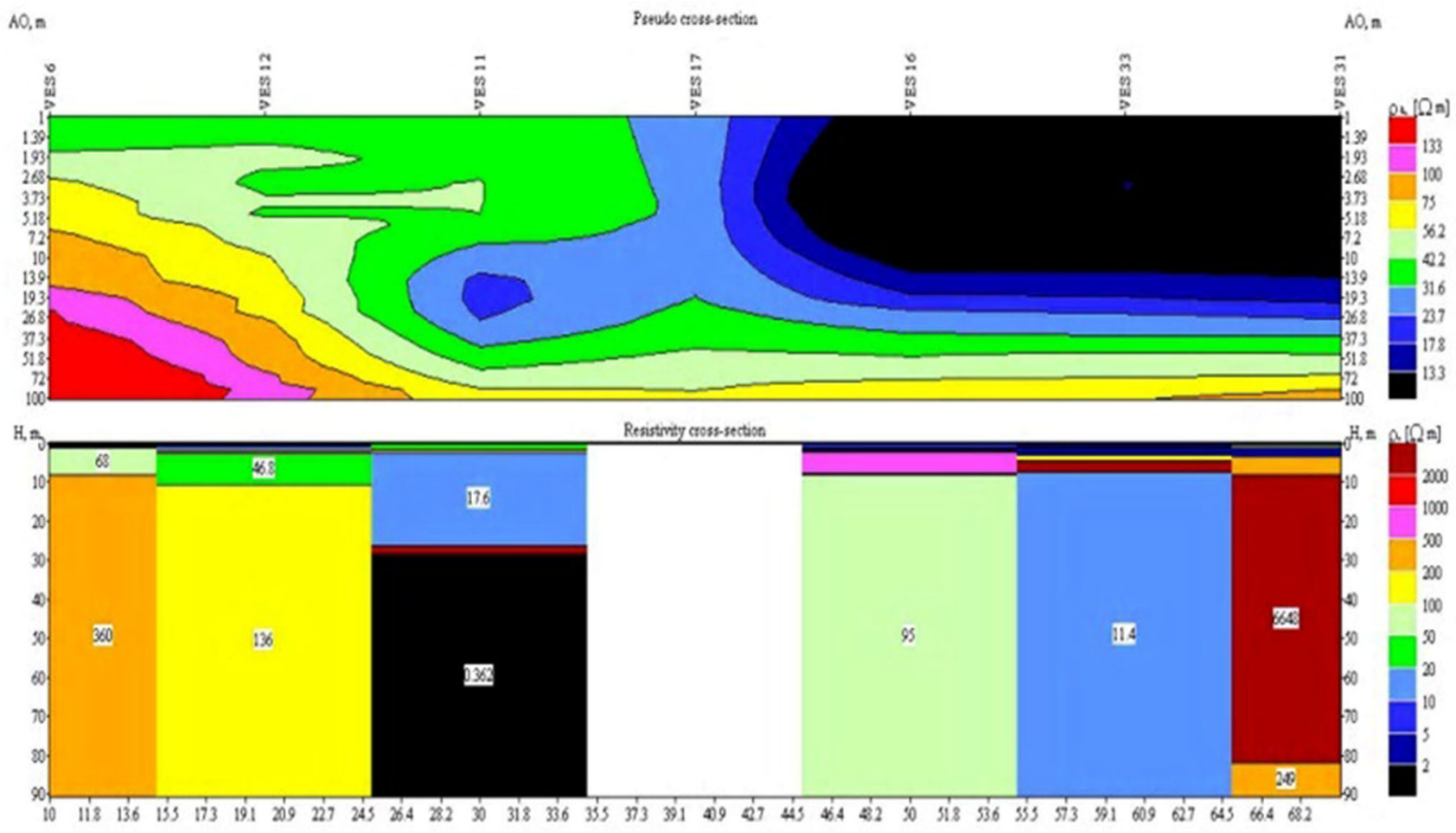

Fig. 12 Apparent and true resistivity geo-electric section along NE-SW from Dhule district

weathered basalts or black cotton soil/murum. Thickness varies from 1.55 to $97.4 \mathrm{~m}$.

\section{Shindkheda taluka}

First layer The resistivity range varies from 14 to $52.8 \Omega \mathrm{m}$. Value between 10 and $100 \Omega \mathrm{m}$ is observed in all VES of Shindkheda taluka which shows highly weathered basalts. Thickness varies from 0.5 to $1.25 \mathrm{~m}$.
Second layer The resistivity range varies from 3.57 to $477 \Omega \mathrm{m}$. The value more than $100 \Omega \mathrm{m}$ is observed in VES no. 19, 21, 23, and 24 which is weakly fractured to hard compact basalts. The values between 10 and $100 \Omega \mathrm{m}$ are observed in VES no. 15, 17, 22, 25, and 26 which show highly weathered basalts. The values less than $10 \Omega \mathrm{m}$ are observed in VES no. 16, 18, and 20 which show the presence of weathered basalts or black cotton soil/murum. Thickness varies from 0.109 to $8.427 \mathrm{~m}$. 


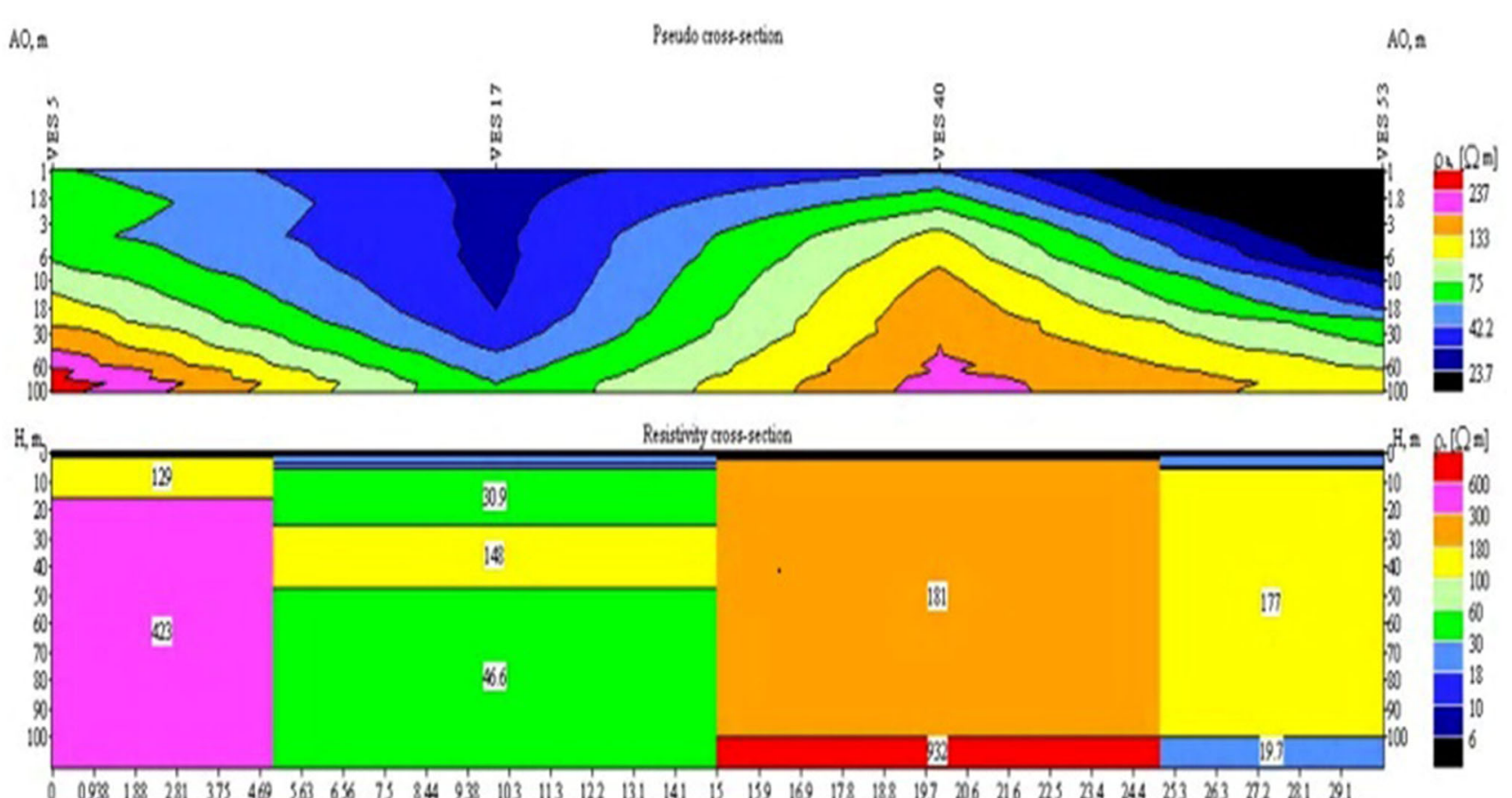

Fig. 13 Apparent and true resistivity geo-electric section along NW-SE from Dhule district

Third layer The resistivity range varies from 0.347 to $426 \Omega \mathrm{m}$. More than $100 \Omega \mathrm{m}$ is observed in VES no. 16 and 22 which is found to be weakly fractured to hard compact basalts. The values between 10 and $100 \Omega \mathrm{m}$ are observed in VES no. 15, 17, 18, 19, 20 21, 23, 25, and 26 which show highly weathered basalts. The values less than $10 \Omega \mathrm{m}$ are observed in VES no. 24 of weathered basalts or black cotton soil/murum. Thickness varies from 0. 0799 to $28 \mathrm{~m}$.

Fourth layer The resistivity range varies from 8.47 to $725 \Omega \mathrm{m}$. More than $100 \Omega \mathrm{m}$ is observed in VES no. 15 , $16,19,20,21,22,23$, and 24 showing weakly fractured to hard compact basalts. The values between 10 and $100 \Omega \mathrm{m}$ are observed in VES no. 17, 18, 25, and 26 which show highly weathered basalts. Thickness varies from 1.2 to $24 \mathrm{~m}$.

Fifth layer The resistivity range varies from 13 to $11,156 \Omega \mathrm{m}$. More than $100 \Omega \mathrm{m}$ is observed in VES no. $17,19,21,23,24,25$, and 26 which is weakly fractured to hard compact basalts. The values between 10 and $100 \Omega \mathrm{m}$ are observed in VES no. 15, 16, 18, 20, and 22 of highly weathered basalts. Thickness varies from 1.22 to $78.6 \mathrm{~m}$.

\section{Shirpur taluka}

First layer The resistivity range varies from 2.9 to $23.1 \Omega \mathrm{m}$. The values between 10 and $100 \Omega \mathrm{m}$ are observed in VES no. 28, 30, 32, and 34 which suggest cotton soil with calcified soil. The values less than $10 \Omega \mathrm{m}$ are observed in VES no. 27, 29, 31, and 33 which show black cotton soil with sand and occasional clays. Thickness varies from 0.5 to $0.953 \mathrm{~m}$.

Second layer The resistivity range varies from 9.43 to $231 \Omega \mathrm{m}$. Value more than $100 \Omega \mathrm{m}$ is observed in VES no. $27,29,30$, and 34 of highly fractured basalts. The values between 10 and $100 \Omega \mathrm{m}$ are observed in VES no. 31 and 33 which show the presence of highly weathered basalts with murum. The values less than $10 \Omega \mathrm{m}$ are observed in VES no. 28 and 32 of black cotton soil with sand and clay. Thickness varies from 0.277 to $2.98 \mathrm{~m}$.

Third layer The resistivity range varies from 0.347 to $20.2 \Omega \mathrm{m}$. The values less than $10 \Omega \mathrm{m}$ are observed in all VES except VES $34(20.2 \Omega \mathrm{m})$ with black cotton soil and black cotton soil with sand. Thickness varies from 0.0799 to $9.98 \mathrm{~m}$. 
Fourth layer The resistivity range varies from 3.02 to $1077 \Omega \mathrm{m}$. More than $100 \Omega \mathrm{m}$ is observed in VES no. 29, 30,31 , and 33 of weakly fractured to hard compact basalts. The values less than $10 \Omega \mathrm{m}$ are observed in VES no. 27 , 28,32 , and 34 which show the presence of alluvium, sand, and clay. Thickness varies from 1.11 to $22.1 \mathrm{~m}$.

Fifth layer The resistivity range for the fifth layer varies from 17.6 to $11,317 \Omega \mathrm{m}$. Value more than $100 \Omega \mathrm{m}$ is observed in VES no. 27, 28, 29, 30, 31, and 32 showing weakly fractured to hard compact basalts. The values between 10 and $100 \Omega \mathrm{m}$ are observed in VES no. 34 of highly weathered basalts. Thickness varies from 3.22 to $72.5 \mathrm{~m}$.

\section{Dhule taluka}

First layer It is observed that resistivity range for the first layer varies from 3.97 to $299 \Omega \mathrm{m}$. The value more than $100 \Omega \mathrm{m}$ is observed in VES no. $37,38,43,44,47,50$, and 51 of weakly fractured to hard compact basalts. The values between 10 and $100 \Omega \mathrm{m}$ are observed in VES no. 35, 36, $39,40,41,46,49$, and 54 with highly weathered basalts. The value less than $10 \Omega \mathrm{m}$ is observed in VES no. 42, 45, 48,52 , and 53 and it shows the presence of weathered basalts/murum. Thickness varies from 0.5 to $2.02 \mathrm{~m}$.

Second layer The resistivity range varies from 0.582 to $1165 \Omega \mathrm{m}$. More than $100 \Omega \mathrm{m}$ is observed in VES no. 38, $40,43,44,45,47$, and 54 to be of weakly fractured to hard compact basalts. The values between 10 and $100 \Omega \mathrm{m}$ are observed in VES no. 35, 42, 46, and 48 which show highly weathered basalts. The values less than $10 \Omega \mathrm{m}$ are observed in VES no. 36, 37, 39, 41, 49, 50, 51, 52, and 53 with the presence of weathered basalts/murum. Thickness of this varies from 0.0296 to $7.34 \mathrm{~m}$.

Third layer The resistivity range varies from 5.6 to $6606 \Omega \mathrm{m}$. More than $100 \Omega \mathrm{m}$ is observed in VES no. 35, $36,37,38,39,41,43,47,49,50,51$, and 52 to be of weakly fractured to hard compact basalts. The values between 10 and $100 \Omega \mathrm{m}$ are observed in VES no. 40, 42, 44, 45, 46, 53, and 54 of highly weathered basalts. Less than $10 \Omega \mathrm{m}$ is observed in VES no. 48 of weathered basalts or murum. Thickness of this varies from 0.102 to $14.3 \mathrm{~m}$.

Fourth layer The resistivity range varies from 5.24 to $4859 \Omega \mathrm{m}$. Value more than $100 \Omega \mathrm{m}$ is observed in VES no. $37,38,40,41,42,44,45,49,52,53$, and 54 to be of weakly fractured to hard compact basalts. The values between 10 and $100 \Omega \mathrm{m}$ are observed in VES no. 35, 39, $43,46,47,48,50$, and 51 which show highly weathered basalts. The values less than $10 \Omega \mathrm{m}$ are observed in VES no. 36 of weathered basalts or murum. Thickness of this varies from 0.198 to $98.1 \mathrm{~m}$.

Fifth layer The resistivity range varies from 0.356 to $68,230 \Omega \mathrm{m}$. The value more than $100 \Omega \mathrm{m}$ is observed in VES no. 35, 36, 37, 38, 39, 40, 43, 47, 48, 50, 51, and 53 to be of weakly fractured to hard compact basalts. The values between 10 and $100 \Omega \mathrm{m}$ are observed in VES no. 41 and 54 which show highly weathered basalts. Variation in the values for different layers suggests the change in lithology in different talukas. The thickness also varies for each layer. Compared with the relief of the district, the variation in the lithologs supports the findings.

\section{Conclusion}

In Wenner configuration, it is observed that it is difficult to operate, since the depth to spread ratio is $1: 3$. Therefore, it is difficult or not possible to record values beyond the depth of $100 \mathrm{~m}$. Since the method used is of inverse slope type, the resistivity of each layer can be calculated separately. This method when compared with the exposed well section matched with the resistivity. Therefore, it is easy to calculate and interpret manually without using the curve matching technique. This reduces the error. It is recommended to use the Wenner's inverse slope method for hard rock terrain.

In Schlumberger method, the observed value of $R$ is used for calculation. The software has the option for the taking care of the errors for matching with the standard curves. In doing so, the original values of the layers may vary and the interpretation may differ depending upon the person handling it. The Schlumberger method is easy to operate, because it is less time consuming, and in short spread of current electrodes, spacing greater depth can be achieved. It is not an easy task to interpret the data by the curve matching technique as it is executed manually. Consideration of number of layers is difficult, because if more layers are demanded, then adjustment through the software during reduction in the number of curves will have an effect on the thickness of the first layer which will be automatically adjusted. Identifying different curves is also time consuming.

Both the Wenner and Schlumberger methods cannot be applied, where there is urban development as well as village community areas, because there is no space for lateral spread of the electrodes. Therefore, care should be taken while giving suitable sites. To use Schlumberger method in hard rock, terrain will still require more detailed survey. In both the cases, it is necessary to have dry surface for effective penetration of the current. If the ground is wet or enough, moisture is present in the ground and it is likely that the current will not penetrate the ground. 
In all the above cases for both methods, the sites given for consideration as positive sites have been successful with respect to the strata obtained through the instrument and actual lithology observed at the site along with the amount of the water that was announced.

Some of the common problems faced during the electrical resistivity methods are loss of resolution, where saline and clarets' soil are present when using Wenner method for greater depth and to some extent lateral variations in electrical properties. Variable water quality may show variation, and limitations are seen for depth of investigation for Wenner method. The applications of resistivity techniques for VES methods of Wenner and Schlumberger are useful in determining bedrock depth. Thin layers are difficult to detect, because there is possibility of being average and merged with overlying or underlying layer.

Based on the interpretation of geo-electrical data, the following conclusions are drawn:

1. Vertical electrical sounding results give information about the subsurface strata as the resistivity obtained from different depths is indicative of the type of strata present.

2. Clay layer associated with alluvium may act as restriction. Vertical electrical sounding survey shows clay layers in Shirpur taluka, where groundwater occurs in alluvial aquifer.

3. The general litho log has a top layer of soil and black cotton soil followed by murum and weathered basalt, then a layer of highly jointed and fracture basalt with base of compact and or hard massive basalt.

4. Interpretation of the VES indicates the presence of an unconfined weathered zone aquifer, alluvial aquifer, and confined aquifer below the hard and massive basalt.

5. The unconfined aquifer is located at an average of $10.6-12.2 \mathrm{~m}$ in Sakri, in Dhule, it is $18.2-19.8 \mathrm{~m}$, and in Shindkheda, it is $16.7-18.2 \mathrm{~m}$.

6. The confined aquifer is observed to be at an average of $106.5-152.4 \mathrm{~m}$ except in Shirpur, where it is $61-76.2 \mathrm{~m}$.

7. The Wenner and Schlumberger data suggest the similar type of layers present in the area with a little difference in the values of resistivity.

\section{Based on the data from VES of Wenner and Schlumberger method, suggestions made are}

1. Most part of the district (Sakri, Dhule, and parts of Shindkheda) is underlain by Deccan Trap basalt; therefore, only Dug wells are feasible structures.

2. Careful selection of sites for bore wells should be carried out with scientific investigation.
3. The overall stage of groundwater development is $53.55 \%$; therefore, there is a scope for further development of groundwater particularly in Dhule, Sakri, and Shindkheda taluka. Care should be taken during planning for use of groundwater. This is important because of the fact that residing water level trends is observed periodically repeated every 8-12 years.

4. Since the stage of groundwater development has reached to a level of about $78 \%$ in Shirpur taluka; hence, future groundwater development is not feasible. Even if there is demand for more groundwater, then it is advised to take all possible measures, so that the stage does not go beyond $80 \%$. This can be achieved by carrying out various artificial recharge methods. The same will be the case, where the groundwater is identified as semi-critical, critical, and over-exploited watersheds.

5. The structures recommended for artificial recharge in the hilly regions of Deccan Trap basalt in the central part can be contour bunds, gully plugs, nala bunds, and check dams. The dug wells can also be treated for artificial recharge with proper maintenance. For alluvial area, especially in Shirpur taluka, percolation tanks and recharge wells or shafts can be constructed.

6. Thus, the future groundwater conservation and recharge structures need to be prioritized. The fractured/weathered basement constituted the major aquifer in the area based on their thick over burden and relatively low resistivity values. The overburden thicknesses, respectively, could be a good area for groundwater exploration.

Acknowledgements Authors thank to Principal, Z. B. Patil College, Dhule for providing research facilities. The co-operation of North Maharashtra University, Jalgaon officials is also acknowledged. Sincere thanks to Dr. Md. Babar, Department of Geology, D. S. M. College, Parbhani (M.S.) India for his constructive suggestions. The author would like to thank unknown reviewers for their valuable comments and suggestions, which improved the quality of this manuscript. The author (RBG) also acknowledges the officials of G.B. Tatha Tatyasaheb Khare Commerce, Parvatibai Gurupad Dhere Art's and Shri. Mahesh Janardan Bhosale Science College, Guhagar Dist. Ratnagiri (India).

Open Access This article is distributed under the terms of the Creative Commons Attribution 4.0 International License (http:// creativecommons.org/licenses/by/4.0/), which permits unrestricted use, distribution, and reproduction in any medium, provided you give appropriate credit to the original author(s) and the source, provide a link to the Creative Commons license, and indicate if changes were made.

Author contributions Conception and design of the work: Baride Mukund Vasantrao, data collection: Patil Jitendra Bhaskarrao, data analysis and interpretation: Baride Mukund Vasantrao and Golekar Rushikesh Baburao, critical revision of the article: Baride Aarti 
Mukund and Patil Sanjaykumar Narayan, and final approval of the version to be published: Golekar Rushikesh Baburao.

\section{References}

Adhyalkar PG (1975) Palaeogeographical frame work of sedimentation and groundwater potentiality of the upland alluvial valleys of India. Maharashtra state, Bombay, Govt. Print. And Stationery, Bombay, 261

Adhyalkar PG, Mani VVS (1972) Geohydrological study in parts of Solapur district and its bearing on feasibility of tube wells in the Deccan Traps. Curr Sci 42(12):444-445

Alisiobi AR, Ako BD (2012) Groundwater Investigation Using Combined Geophysical Methods. AAPG Annual Convention and Exhibition, Long Beach, California Search and Discovery, Article 40914

Andrade R (2011) Intervention of electrical resistance tomography in resolving hydrological problems of a semi arid granite terrain as Southern India. J Geol Soc India 78:337-344

Ariyo SO, Folorunso AF, Ajibade OM (2011) Geological and geophysical evaluation of the Ajana area's groundwater potential, southwestern Nigeria. Earth Sci Res J (ESRJ) 15(1):35-40

Aurangabadkar KP (1990) Investigation of potential Areas for Artificial recharge in Burai Basin, Dhule district. Proc. Seminar on Modern techniques of Rainwater harvesting, Water conservation and Artificial Recharge for drinking water, Afforestation, Horticulture and Agriculture. R.D.D. and GSDA. Pune. 482-490

Aurangabadkar KP, Waldhe VJ (2001) Artificial Recharge project for wells tapping alluvial aquifers in Bamnod area District Jalgaon. Proc. Vol. of International seminar on an Integrated Approach for strengthening and protecting Drinking Water Sources at GSDA, Pune. 387-406

Ayolabi EA (2005) Geoelectric evaluation of groundwater potential: a case study of Alagbaka primary school, Akure, Southwest Nigeria. J Geol Soc India 66:491-495

Babachev AA (1994) IPI2 Win software. http://geophys.geol.msu.ru

Babiker M, Gudmundsson A (2004) The effects of dykes and faults on groundwater flow in an arid land: the Red Sea Hills, Sudan. J Hydrol 297:256-273

Bhattacharji S, Sharma R, Chatterjee N (2004) Two- and three dimensional gravity modelling along west continental margin and intraplate Narmada-Tapi rifts: its relevance to Deccan flood basalt volcanism. Proc Indian Acad Sci (Earth Planet Sci) 113:771-784

Bhattacharya PK, Patra HP (1968) Direct current geoelectric sounding. Elsevier, Amsterdam

Blanford WT (1869) On the geology of the Tapti and Lower Narmada valleys and some adjoining districts. Mem Geol Surv India $6: 163-384$

Bondre NR, Hart WK, Sheth HC (2006) Geology and geochemistry of the Sangamner dyke swarm, western Deccan volcanic province: implications for regional stratigraphy. J Geol 114:155-170

Central Ground Water Board (2009) Manual on hydrogeology of Dhule district. Maharashtra CGWB, Nagpur

Das Balaram Maity SK, Tarafdar ON (2007) Application of electrical resistivity and induced polarisation methods for detection of fluoride contaminated groundwater. J Geol Soc India 69:381-389

Deshpande SM (2008) Geophysical studies of groundwater occurrence in and around Satara village, district Aurangabad, Maharashtra. Gondwana Geol Magz 23(2):163-165

Duraiswami RA (2005) Dykes as potential groundwater reservoir in semi-arid areas of Sakri taluka, Dhule district, Maharashtra. Gondwana Geol Magz 21(1):1-9
Erram VC, Gupta G, Pawar JB, Kumar S, Pawar NJ (2010) Potential groundwater zones in parts of Dhule District, Maharashtra: a joint interpretation based on resistivity and magnetic data. J India Geol Congr 2(1):37-45

Geological Survey of India (1976) Geology of Dhule district, Maharashtra, 125 th year celebration publications

Geological Survey of India (2001) District resource map-Dhule district, Maharashtra

Golekar RB, Baride MV, Patil SN (2014) 1D resistivity sounding geophysical survey by using Schlumberger electrode configuration method for groundwater explorations in catchment area of Anjani and Jhiri river, Northern Maharashtra (India). J Spatial Hydrol 12(1):22-35

GSDA (2001) Ground Water Survey Development Agency (GSDA)

Gupta G, Erram VC, Kumar S (2012) Temporal geoelectric behaviour of dyke aquifers in northern Deccan Volcanic Province, India. J Earth Syst Sci 121:723-732

Gurugnanam B, Devarajan M, Pugazhandi V, Prabhakaran N, Suvedha M (2008) Locating the aquifer extent I terms of spatial distribution through geo-physics and GIS in Ayothiyapattinam Block, Salem district, Tamilnadu. J Appl Hydrol 21:23-32

Krishnamurthy NS, Ananda Rao V, Kumar D, Singh KKK, Ahmed S (2009) Electrical resistivity imaging technique to delineate coal seam barrier thickness and demarcate water filled voids. J Geol Soc India 73:634-650

Krishnan MS (1982) Geology of India and Burma, 6th edn. CBS, Publications, New Delhi, p 536

Kumar D, Thiaghrajan S, Rai SN (2011) Deciphering geothermal resource in Deccan trap region using electrical resistivity tomography technique. J Geol Soc India 78:541-548

Melluso L, Sethna SF, Morra V, Khateeb A, Javeri P (1999) Petrology of the mafic dyke swarm of the Tapti River in Nandurbar area (Deccan Volcanic Province). Geol Soc India Mem 43:735-755

Narayan PVS, Ramanujachary KR (1967) An inverse slope method determining absolute resistivity. J Geophys 32:1036-1040

Ojelabi EA, Basorun OA, Badmus BS, Ariyo SO, Oyedele KF, Akintunde OM (2001) Geoelectric sounding near Ijebuode and its implication on groundwater exploration. J Sci Eng Technol 8(4):3700-3708

Orellana E, Mooney HM (1972) Two and three layer master curves and auxiliary point diagrams for vertical electrical soundings using Wenner arrangement: Madrid, Spain. Interciencia 43 sheets

Orellena E, Mooney HM (1966) Master tables and curves of vertical electrical sounding over layered structures. Interciencia, Madrid, pp 150-166

Patangay NS, Ramaprasada Rao IB, Venkata Chary M, Mathur RR, Shiva Keshvulu A, Sriniva SRP (2002) Application of geophysical techniques to trace groundwater pollution due to industrial effluents in the hard rock terrain. J Geophys 23(1):9-12

Pawar JB (2006) Hydrogeology of Upper Panzra basin with special reference to role of Dykes in the occurrence and movement of groundwater, District Dhule, Maharashtra, Unpublished thesis, University of Pune, 207

Powar KB (1987) Evolution of the Deccan volcanic Province, Presidential Address, 74th session, Geology and Geography Section, Indian Science Congress, 29

Ray R, Sheth HC, Mallik J (2007) Structure and emplacement of the Nandurbar-Dhule mafic dyke swarm, Deccan Traps, and the tectonomagmatic evolution of flood basalts. Bull Volcano 69(5):537-551

Sant DA, Karanth RV (1990) Emplacement of dyke swarms in the Lower Narmada Valley, western India. In: Parker AJ, Rickwood PC, Tucker DH (eds) Mafic dykes and emplacement mechanisms. Proceedings of the 2nd international dyke conference, 
Adelaide, 12-16 September 1990. Bulkema, Rotterdam, pp 383-389

Sethna SF, Ateehq K, Javeri P (1996) Petrology of basic intrusive in the Deccan volcanic province South of Tapti valley and their comparison with those along the west coast. Gondwana Geol Magz Spl 2:225-232

Sheth HC (2005) Were the Deccan flood basalts derived in part from ancient oceanic crust within the Indian continental lithosphere? Gondwana Res 8(2):109-127

Sheth HC, Chandrasekharam D (1997) Early alkaline magmatism in the Deccan Traps: implications for plume incubation and lithospheric rifting. Phys Earth Planet Inter 104(4):369-375

Sheth HC, Pande K (2004) Magmatism in India through time. Proc India Acad Sci (Earth Planet Sci) 113:517-838

Singh RP, Jamal A (2002) Dykes as groundwater loci in parts of Nashik district, Maharashtra. J Geol Soc India 59(2):143-146

Singh VB, Tripathi JN (2009) An investigation of groundwater condition using geo-electrical resistivity method: a case study from some parts of Kaushambi district (UP), India. J Spatial Hydrol 9(2):20

Srinivasamoorthy K, Chidambaram S, Vasanthaviger M (2009) Identification of ground water recharge zones in a hard rock terrain using electrical resistivity methods. J Appl Hydrol 22:68-79

Swartz JH (1937) Resistivity studies of some salt-water boundaries in the Hawaiian Islands. Am Geophys Union 18:387-393
Sykes (1833) http://www.portal.gsi.gov.in

Todd DK (1959) Annotated bibliography on artificial recharge of ground water through 1954. Geological survey water-supply paper 1477. United States Government Printing-Office, Washington, p 119

Udaya Laxmi G, Ramadass G (2009) VES approach for delineating contaminated groundwater zones is Osmania University and surrounding areas of greater Hyderabad, South India. Gondwana Geol Magz 24(1):11-18

Vaidyanadhan R, Ramakrishnan N (2008) Geological Society of India, Bangalore. Geol India 1:994

Wenner DL (1969) Preliminary field studies using earth resistivity measurements for delineating zones of contaminating ground water. Gr Water 7(1):9-16

West WD (1972) Presidential address, Symp. Deccan Trap and other flood basalts. Bull Volcano 35:513-518

West WD (1988) http://www.protal.gsi.gov.in

Zambre MK, Thigale SS (1980) Geophysical investigation for groundwater in Solapur district, Maharashtra. Proc 3rd India Geol Congr Poona 435-443

Zohdy AAR, Eaton GP, Mabey DR (1974) Application of surface geophysics to groundwater investigations, technique of water resource investigation of the US. Geol Surv Chapter D Book $2: 116$ 